\title{
Permaculture for agroecology: design, movement, practice, and worldview. A review
}

\author{
Rafter Sass Ferguson • Sarah Taylor Lovell
}

Accepted: 17 September 2013 /Published online: 25 October 2013

(C) INRA and Springer-Verlag France 2013. This article is published with open access at Springerlink.com

\begin{abstract}
Agroecology is a promising alternative to industrial agriculture, with the potential to avoid the negative social and ecological consequences of input-intensive production. Transitioning to agroecological production is, however, a complex project that requires diverse contributions from the outside of scientific institutions. Agroecologists therefore collaborate with traditional producers and agroecological movements. Permaculture is one such agroecological movement, with a broad international distribution and a unique approach to system design. Despite a high public profile, permaculture has remained relatively isolated from scientific research. Though the potential contribution of permaculture to agroecological transition is great, it is limited by this isolation from science, as well as from oversimplifying claims, and the lack of a clear definition. Here, we review scientific and popular permaculture literature. A systematic review discusses quantitative bibliometric data, including keyword analysis. A qualitative review identifies and assesses major themes, proposals, and claims. The manuscript follows a stratified definition of permaculture as design system, best practice framework, worldview, and movement. The major points of our analysis are as follows: (1) Principles and topics largely complement and even extend principles and topics found in the agroecological literature. (2) Distinctive approaches to perennial polyculture, water management, and the importance of agroecosystem configuration exceed what is documented in the scientific literature and thus suggest promising avenues of inquiry. (3) Discussions of practice consistently underplay the complexity, challenges, and risks that producers face in developing diversified and integrated production systems. (4) The movement
\end{abstract}

R. S. Ferguson $(\bowtie)$

1105 Plant Sciences Laboratory, University of Illinois at

Urbana-Champaign, 1201 S. Dorner Dr., Urbana, IL 61801, USA

e-mail: fergusn2@illinois.edu

S. T. Lovell

1009 Plant Sciences Laboratory, University of Illinois at

Urbana-Champaign, 1201 S. Dorner Dr., Urbana, IL 61801, USA is mobilizing diverse forms of social support for sustainability, in geographically diverse locations. (5) And scholarship in permaculture has always been a diverse marginal sector, but is growing.

Keywords Permaculture $\cdot$ Farm design $\cdot$ Perennial polyculture $\cdot$ Agroecological transition $\cdot$ Diversified farming systems $\cdot$ Agroecological movement

Contents

1. Introduction $\ldots \ldots \ldots \ldots \ldots \ldots \ldots \ldots \ldots \ldots$

2. Background ...................... 3

2.1 Shifting Definitions $\ldots \ldots \ldots \ldots \ldots \ldots \ldots \ldots$

2.2 Historical Context ..................... 3

2.3 Conceptual Influences ................... 3

2.4 Permaculture and Agroecology .............. 4

3. Review Methods ........................ 5

3.1 Systematic Review..................... 5

3.2 Qualitative Review................. 7

4. Results ....................... 7

4.1 Systematic and Bibliometric Review . . . . . . . 7

4.2 Qualitative Review ..................... 11

5. Synthesis ...................... 16

5.1 Substantiation and Scholarship ............. 17

5.2 Limitations of this Study . . . . . . . . . . . . 18

5.3 Future Directions ..................... 19

6. Conclusion ..................... 20

\section{Introduction}

Increasing concerns about the negative impacts of industrial agriculture have generated a vigorous debate over the feasibility of transition to alternative forms of agriculture, capable of providing a broad suite of ecosystem services while 
producing yields for human use. The transition to diversified, ecologically benign, smaller scale production systems is addressed in the literature of agroecology (De Schutter 2010), diversified farming systems (Kremen et al. 2012), and multifunctional agriculture (Wilson 2008). Agroecological transition must be regarded as a complex, multi-sector project, operating at multiple temporal and spatial scales and involving diverse constituencies (Geels and Kemp 2007; Marques 2010; Piraux et al. 2010). For this reason, researchers have often directed their attention outside of institutional science to document the contributions that traditional and innovative practices offer to the process of transition (Altieri 2004; Ingram 2007; Rocha 2005; Koohafkan et al. 2012; Rosset et al. 2011). Alternative agroecology movements, for example, have been critical in the process of regional agroecological transition (Nelson et al. 2009; Altieri and Toledo 2011) and likely will be in the future (Fernandez et al. 2012; Petersen et al. 2012).

This paper addresses the alternative agroecology movement called permaculture and its potential contributions to agroecological transition. Permaculture is an international movement and ecological design system (Fig. 1). Despite permaculture's international extent and relatively high public profile, it has received very little discussion in the scientific literature. The term originated as a portmanteau of permanent agriculture and is defined by co-originator David Holmgren as "Consciously designed landscapes which mimic the patterns and relationships found in nature, while yielding an abundance of food, fibre and energy for provision of local needs" (2004, p. xix). As a broadly distributed movement with a distinctive conceptual framework for agroecosystem design, permaculture's relevance to the project of agroecological transition has several aspects. Permaculture can function as a framework for integrating knowledge and practice across disciplines to support collaboration with mixed groups of researchers, stakeholders, and land users. Permaculture contributes to an applied form of ecological literacy (Orr 1992), supplying a popular and accessible synthesis of complex socioecological concepts. The design orientation of permaculture offers a distinctive perspective that suggests avenues of inquiry in agroecosystem research. Lastly, these factors are embodied in an international movement that operates largely outside of the influence and support of large institutions, which suggests opportunities for participatory action research and the mobilization of popular inquiry and support (Méndez et al. 2013).

The potential of permaculture to contribute broadly to agroecological transition is limited by several factors. Of primary importance is the general isolation of permaculture from science, both in terms of a lack of scholarly research about permaculture and neglect within the permaculture literature of contemporary scientific perspectives. This deficit is compounded by overreaching and oversimplifying claims made by movement adherents and the absence of any systematic multisite assessment of permaculture's impacts. Additionally, the difficulty of providing a clear and distinguishing description of permaculture can cause confusion and hinder rigorous and systematic discussion.

The objective of this paper is to contribute to a better understanding of the substance, strengths, and limitations of permaculture as a potential contributor to agroecological transition. Introductory material includes a brief overview of the origins and development of permaculture, the growth of the movement over time, and a preliminary heuristic for comparing the prominence and overlap of permaculture and agroecology across several sectors. The introduction is followed by a systematic review of scientific and popular permaculture literature, analyzing publication type, date, and location, topic location, scholarly discipline, and citations. Systematic analysis also includes quantitative content analysis using a concept
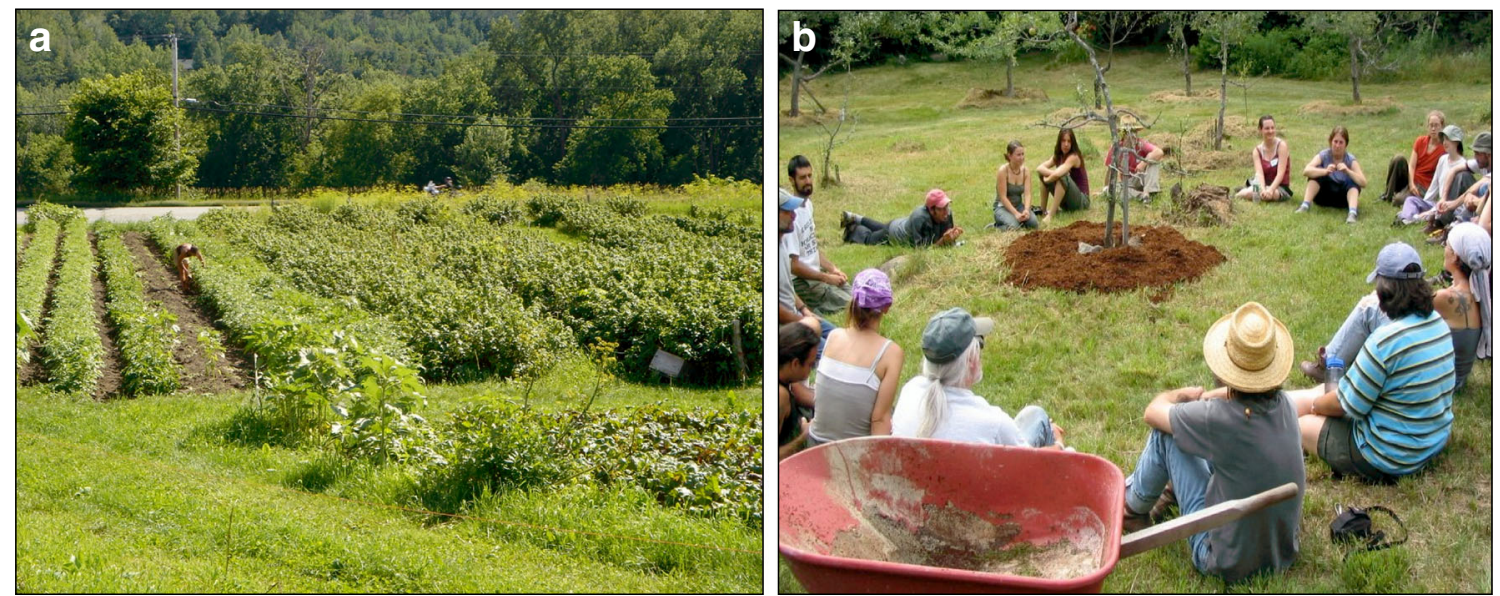

Fig. 1 Examples of production and education in the permaculture movement. a Small farm with intercropped annuals and perennials, worked partially with hand labor. b Workshop on the design and maintenance of perennial polycultures 
network approach. Qualitative review of the permaculture framework then identifies and evaluates prominent themes in the permaculture literature, focusing on agroecological topics. Finally, qualitative and quantitative analyses are synthesized to produce an overall evaluation of permaculture, including recommendations for future directions for research and dialog.

\section{Background}

\subsection{Shifting definitions}

The definition of permaculture varies among sources and displays an expansion in subject area over time. In 1978, permaculture was defined in the founding text as "an integrated, evolving system of perennial or self-perpetuating plant and animal species useful to man ... in essence, a complete agricultural ecosystem, modeled on existing but simpler examples" (Mollison and Holmgren 1978, p. 1). By 1988, the definition had grown in scope to encompass broader issues of human settlement while maintaining a core agricultural focus: "Permaculture ... is the conscious design and maintenance of agriculturally productive ecosystems which have the diversity, stability, and resilience of natural ecosystems. It is the harmonious integration of landscape and people providing their food, energy, shelter, and other material and non-material needs in a sustainable way" (Mollison). While permaculture addresses multiple aspects of human settlement, this paper will focus primarily on those aspects of permaculture relevant to agriculture and agroecological transition.

\subsection{Historical context}

Permaculture emerged in parallel with other movements and disciplines with a focus on sustainability. In the past 50 years, concerns over the negative social and environmental impacts of urbanization, industrial agriculture, and resource extraction and depletion have expanded dramatically (De Steiguer 2006; Hawken 2007; McCormick 1991). Over this period, public and scientific concern for environmental degradation has spread from isolated voices, through environmental movements and emerging scientific disciplines, and into mainstream science and popular culture (FitzSimmons et al. 1991). Environmental movement participants have produced diverse proposals for alternative food production (Lockeretz 2007), international development (Dahlberg 1979; Cole 1981), generating energy (Clark 1975), and planning settlements (Alexander 1977). In parallel, and often intersecting with, the proposals of environmental and social movements, scientists, and development professionals have proposed alternative frameworks for managing natural resources and fostering economic development. Through the 1970s and 1980s, agroecology (Wezel and Soldat 2009), agroforestry (Nair 1993), ecological design (Todd 2005), and appropriate technology (Pursell 1993) emerged as movements and disciplines of their own. Other and older approaches, such as organic farming, experienced rapid growth and widespread acceptance (Lockeretz 2007). Many of these alternative frameworks now approach the mainstream, through the incremental accumulation of scientific evidence, institutionalization, or as in the case of organic farming through certification and large-scale commercialization.

Permaculture was founded in the 1970s by Bill Mollison and David Holmgren and now has a presence on every inhabited continent. Permaculture's founders shared broad environmental concerns with the movements described above while focusing specifically on the threat of energy scarcity for energy-intensive agricultural systems (Mollison and Holmgren 1978). Mollison and Holmgren drew on many sources in their development of the permaculture framework, but were especially influenced by the British and US literature of permanent agriculture and the systems ecology/ecological engineering perspective of H.T. Odum (Mollison and Holmgren 1978; Holmgren 2004).

\subsection{Conceptual influences}

\subsubsection{Permanent as sustainable and perennial}

The term permanent agriculture, from which the word permaculture is derived, has multiple uses. Permanent agriculture is used to contrast sedentary, continuous agriculture with shifting cultivation in discussions of the latter (q.v. Rasul and Thapa 2003; Geist and Lambin 2002). Examination of the British and US literature on farming practices in the early 1900s suggests that the word "permanent" was used in an analogous fashion to the current use of the term sustainable (King 1911; Howard 1940). With the publication of Russell Smith's foundational agroforestry text Tree Crops: A Permanent Agriculture, permanent came to connote agricultural systems incorporating a high proportion of perennial species (Smith 1929). It is this concept for which permaculture is named. Mollison and Holmgren adopted Smith's emphasis on the importance of tree crops for soil stabilization in hillside agriculture, production of fodder, and production of complementary and staple foods for human consumption (Mollison and Holmgren 1978). The portmanteau of "permanent agriculture" was later redefined as "permanent culture" as the scope of permaculture expanded from the design of smallholder agriculture to encompass human settlement more broadly (Mollison 1988).

\subsubsection{Systems ecology}

Permaculture's emphasis on whole systems design is heavily influenced by the work of ecologist H.T. Odum (Holmgren 1992). Odum developed the influential framework of systems ecology, a thermodynamic perspective that regards ecosystems as networks through which energy flows and is stored and 
transformed, which can be diagramed and modeled in a manner analogous to electronic circuits (Odum 1994). Odum referred to the applied form of systems ecology as ecological engineering, and this design perspective would shape fundamental components of the permaculture perspective (Holmgren 2004). In the highly cited book Environment, Power, and Society (1971), Odum proposes an approach to the design of novel and productive ecosystems in which species are regarded as distinctive but interchangeable system components which should be selected from a global pool without regard to the place of origin. In this view, the distinctive inputs and outputs of each species will connect in novel assemblages, and the exchanges of energy and resources between system components will substitute for human labor and material inputs. Ecosystem designers should therefore foster self-organization through the iterative "seeding" of diverse species from the global species pool, in order to generate and select ecosystems which produce yields for human use with minimal labor input (Odum 1971, p. 280). The influence of this focus on functional relationships between components, the self-organization of systems, and species selection practices is reflected throughout the permaculture literature (Mollison and Holmgren 1978; Mollison 1988; Holmgren 2004; Hemenway 2009).

\subsubsection{Keyline planning}

Holmgren and Mollison were also informed by the whole landscape approach of the Australian Keyline design system (Holmgren 2004). From the 1950s to the 1970s, farmer and writer P.A. Yeomans developed a system that integrated novel methods for landscape analysis with whole farm water management, agroforestry, soil building strategies (using slightly-offcontour chisel plowing and rotational grazing), and the development of new chisel plow designs for use in the system (Yeomans 1954, 1958, 1971, 1981). Yeoman's Keyline system has received very little attention in the scientific literature. Keyline planning is nevertheless an innovative application of design to agricultural landscapes and shaped the approach taken by Holmgren and Mollison (Mulligan and Hill 2001, p. 202), who adopted many of the concepts of the Keyline plan directly into the developing permaculture framework (Mollison and Holmgren 1978; Mollison 1979).

\subsection{Permaculture and agroecology}

In the past three decades, permaculture has grown in parallel with agroecology, displaying overlapping concerns while developing different constituencies. Permaculture shares with the discipline of agroecology a focus on the intersection of ecology and agricultural production, a normative orientation toward agroecological transition, and an association with popular movements consisting largely of land users. Despite these parallels, permaculture has received very little discussion in the agroecological literature. When permaculture is mentioned, it is frequently found as an item on a list of alternative agricultural frameworks, the value of which is either explicitly in question (Gomiero et al. 2011; Pretty 2006; Bavec et al. 2009; Pretty 2005), or positive but nonspecific (Leakey 2012; Deb et al. 2008; Lovell et al. 2010). Permaculture is elsewhere associated positively, albeit in passing, with agroforestry, perennial polycultures, agroecosystem design, ecosystem mimicry, and agrobiodiversity (Francis and Porter 2011; Torre Ugarte and Hellwinckel 2010). Substantive assessment of permaculture as an approach to agriculture, positive and negative, appears to be absent from the peer-reviewed literature.

This absence is surprising in light of permaculture's international public profile. Parallel queries of online databases for the terms "permaculture" and "agroecology" can be used to illustrate patterns in the relative prominence and overlap of each field across sectors. This fairly crude comparison is presented here (Fig. 2) in a preliminary fashion to demonstrate that the sparse representation of permaculture in the scientific literature is incommensurate with a high level of general interest. The proportions of results returned for each term varied widely across data sources. The scientific databases Web of Knowledge and Google Scholar returned 21 and 6 times as
Fig. 2 Proportional results from parallel search queries for "agroecology" (crosshatch), combined "agroecology" + "permaculture" (solid), and "permaculture" (horizontals), to multiple online data sources, illustrating the uneven relative prominence of agroecology and permaculture across different sectors. Numbers in parentheses indicate combined total responses from each data source

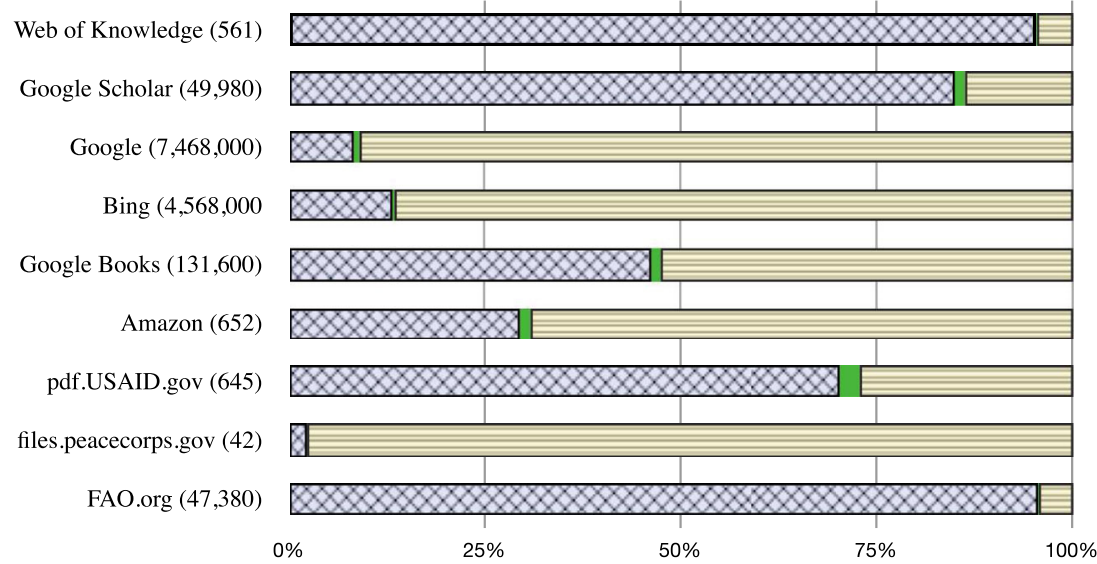


many results for agroecology as for permaculture, respectively, while general purpose internet search engines Google and Bing were skewed in the opposite direction, returning 11 and 7 times as many results for permaculture as for agroecology, respectively. Multipurpose literature databases for book sales were less asymmetrical, with approximately equal results for each term in Google Books and twice the results for permaculture in Amazon. Document archives of international development organizations (US AID, Peace Corps, and FAO) were highly and heterogeneously skewed, respectively, returning 3 times the results for agroecology as for permaculture, 41 times the results for permaculture, and 21 times the results for agroecology.

In addition to the parallels described above, permaculture shares with agroecology a complex stratified definition. Recent scholarship has clarified that agroecology simultaneously refers to a scientific discipline, a social movement, and a set of agricultural practices (Wezel et al. 2009). Similarly, some of the confusion surrounding permaculture may be attributed to the use of the term to refer to a design system, to an international movement, to the worldview carried by and disseminated by the movement, and to the set of associated practices. Figure 3 is a conceptual map intended to clarify the relationship among the different strata that make up permaculture, each of which intersects with the project of agroecological transition. This conceptual structure will be used to organize the examination and assessment of the permaculture literature.

\section{Review methods}

This study integrates multiple review methods to address the challenges of assessing and synthesizing a large and diverse literature, much of which is intended for a popular audience. In the absence of any previous reviews, it is useful to address quantitative questions of what has been published, in what form, where, and about what geographic regions. Qualitative

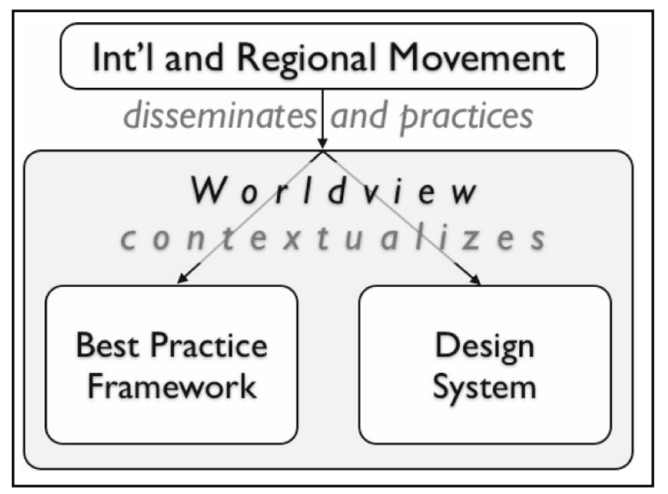

Fig. 3 Stratified definition of permaculture, illustrating the relationships between four common referents of the term. Permaculture is (1) an international and regional movement that disseminates and practices (2) a design system and (3) a best practice framework. The design system and best practice framework are contextualized by (4) the worldview that is carried by the movement review will then address questions of topic, theme, and assessment in terms of current scientific understanding, in order to evaluate the actual and potential contributions of permaculture to agroecological transition.

\subsection{Systematic review}

A systematic review methodology used in numerous previous studies was adapted for application to the body of permaculture literature (Guitart et al. 2012; Wezel and Soldat 2009). The permaculture literature differs from most subjects of systematic review in the large number of publications intended for a popular audience, the large number of book-length publications, the small number of peer-reviewed works, and the absence of experimental design and statistical analysis from almost all works.

\subsubsection{Search protocol}

Parallel searches were conducted on Web of Knowledge (WOK), Google Scholar, International Information System for the Agricultural Sciences and Technology (AGRIS), and Education Resource Information Centre (ERIC), using the search term permaculture. In the case of Google Scholar, the search was constrained to articles with the search term appearing in the title field. While this criterion excluded many works that substantively pertain to permaculture, it avoided including any works for which the relationship with permaculture was ambiguous or trivial. Effort was made to eliminate self-published and exclusively electronic works, unless they were listed as having been cited within Google Scholar, in order to focus on publications for which there was some evidence of readership. Academic theses and dissertations were exempted from this consideration. For WOK, AGRIS, and ERIC, publications with permaculture appearing in any field were included. References for book reviews of works appearing elsewhere in the bibliography were not included. The search protocol was concluded on 18 December 2012. Results included prepublication data on one book chapter slated for publication in April 2013, and the terminal year of the bibliography is therefore 2013 .

While this study addresses English-language literature only, a supplementary search protocol was used for the preliminary identification of concentrations of permaculture literature in other languages. Language localizations of Google Scholar were queried in Spanish, Portuguese, German, French, Arabic, Japanese, and Russian, and the number of search results was recorded and compared to results for the English-language search. No other data were collected for non-English literature.

\subsubsection{Bibliometric analysis}

The search protocol described above was used to assemble the bibliography for analysis. After the elimination of duplicate and spurious results, the bibliography contained 230 references. 
Table 1 Publication types in permaculture bibliography assembled for analysis

\begin{tabular}{ll}
\hline Publication type & Number \\
\hline Journal article & 50 \\
Thesis & 46 \\
Book & 41 \\
Periodical article & 28 \\
Proceedings & 27 \\
Chapter & 15 \\
Report & 11 \\
Miscellaneous & 12 \\
Booklet & 5 \\
Presentation & 2 \\
Meeting abstract & 1 \\
Undergrad, non-thesis & 1 \\
Occasional paper & 1 \\
Interview & 1 \\
Seed catalog & 1 \\
Total & 230 \\
\hline
\end{tabular}

Each reference in the bibliography was identified as book, journal article, graduate thesis, book chapter, conference proceeding, periodical article, or miscellaneous (Table 1). Journal articles included peer-reviewed and non-peer-reviewed works. Periodical articles included magazine, newspaper, and newsletter articles. Scholarly and technical publications were identified as a subset of total publications. Peer-reviewed publications were identified as a subset of scholarly publications.

For scholarly works (including refereed and non-refereed publications), the discipline of the journal (for articles), the academic program (for theses and dissertations), or the conference (for proceedings) was determined. When the institutional discipline could not be determined, the discipline of the author(s) or the apparent discipline of the publication topic was used. Disciplines were sorted into categories according to a three-tiered disciplinary taxonomy that synthesizes seven other major disciplinary taxonomies (bepress 2010). Citation statistics were recorded for each reference. As the majority of the references in the bibliography appeared solely in the Google
Fig. 4 Distribution of publication types in a 230-reference bibliography of permaculture, in 5 -year increments except for 2008-2013. a Distribution of publication types within the biography shows rapid growth in articles and theses since 2008 . b Scholarly publications represent a growing share of the total bibliography over time, with peer-reviewed publications growing at a slower pace

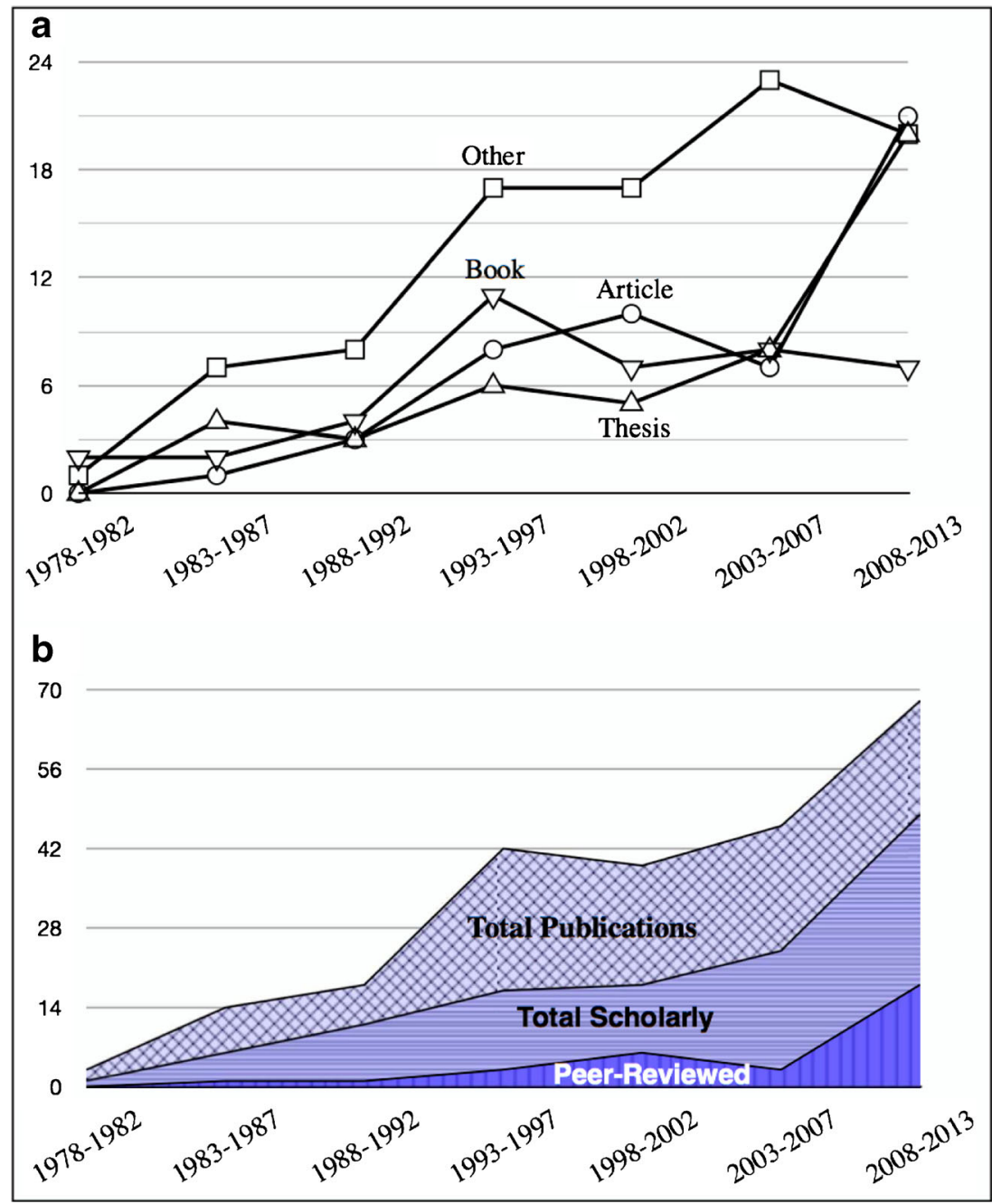


Scholar searches, citation statistics were derived exclusively from Google Scholar queries. The bibliography was analyzed for two geographic values: place of publication and place of topic. Place of publication data was obtained for all references, and a place of topic was identified in 135 references.

\subsubsection{Concept network}

Keywords for each reference were drawn from multiple fields to accommodate the diversity of publication types represented. Title keywords were included for all publications, and author keywords were included whenever present. Abstracts were included for scholarly articles whenever available. Jacket blurbs were included for books whenever available. Textual analysis was carried out with word co-occurrence analysis (He 1999) using a concept network approach (Popping 2003) that incorporates analysis of probabilistic word co-occurrence with relative word position and represents relationships between keywords as a network graph. This quantitative approach to text analysis allows for the exploratory analysis of meaning, context, and change over time, in large bodies of text, while providing an alternative or complement to qualitative coding (He 1999). Keyword text was analyzed in four time frames: the three sequences of 1978-1992, 1993-2002, and 20032013 and also as a complete sequence of 1978-2013. The text of each sequence was submitted individually to the web-based analytical engine Textexture (http://textexture.com/). Textexture performs several pre-analysis processes, including the removal of common and semantically trivial words (including articles, conjunctions, modifiers, etc.) and stemming words using the Krovetz Stemmer algorithm to reduce complexity and redundancy between closely associated words (Paranyushkin 2011). Once the text is prepared, Textexture performs a two-pass analysis to convert text into network data. Scanning first in two-word and then in five-word units, Textexture creates a node for each novel word it encounters and creates or strengthens links between nodes each time words co-occur within a scanning unit (Paranyushkin 2011). Textexture provides its own visualization engine, but for the purposes of this study, the graph data was downloaded as a Graph Exchange XML Format file and visualized using the open-source graphing software Gephi (Bastian et al. 2009). Once loaded into Gephi, each of the four graph files was processed identically. Nodes were sized according to the betweenness centrality (BC) metric, which measures the number of node pairs whose shortest connecting path passes through the target node (Brandes 2001). Nodes were then clustered using a community detection algorithm based on modularity, which identifies groups of nodes whose mutual connections are denser than their connections to the rest of the network (Newman 2006; Paranyushkin 2011). Each cluster was assigned random colors. The size of nodes therefore shows the number of contexts in which each term appears, while color and grouping show the most significant contexts in which each term appears. Edge thickness was determined by weight - the frequency of the word pairs represented by each node. Only 100 most significant nodes from each time frame, by BC, are represented in each graph. All edges with a weight of 1 , signifying that the word pair they connected only co-occurred in a single instance, were filtered from the visualization to enhance readability.

\subsection{Qualitative review}

The texts examined for qualitative analysis included additional publications, not included in the bibliography, selected on the basis of authorship by key movement figures, reference in influential works in the bibliography, or special relevance to themes identified in ongoing analysis. Qualitative analysis also draws on additional nonprint sources, including websites, online discussion platforms, and video. Sources were examined for prominent themes with a bearing on agroecological transition and assessed in relationship to contemporary science. Results from the systematic review were used to triangulate with and inform qualitative analysis.

The high level of redundancy in the permaculture literature has been noted elsewhere (Scott 2010), such that a significant portion of publications devote some space to reiterating foundational material developed in a small number of key publications (Mollison and Holmgren 1978; Mollison 1988; Mollison and Holmgren 1978; Holmgren 2004). Key publications will be cited when the intent is to clarify origins, while multiple derivative publications will be cited when the intent is to illustrate prevalence.

\section{Results}

\subsection{Systematic and bibliometric review}

In this section, the results of the systematic and bibliometric analyses are presented, including publication type, citations, publication and topic geography, scholarly discipline, and concept network.

\subsubsection{Publication type}

The three most prolific publication types in the bibliography were journal article (50), graduate thesis (46), and book (41). While journal articles and theses are most numerous, when publication length is considered, it is clear that books represent the bulk of published content on permaculture. Along with overall growth in publications, the distribution of publication types changes over time (Fig. 4a), and the three publication types showing the most growth in per year publications were journal articles (from 0 to 21 ), graduate theses ( 0 to 20 ), 


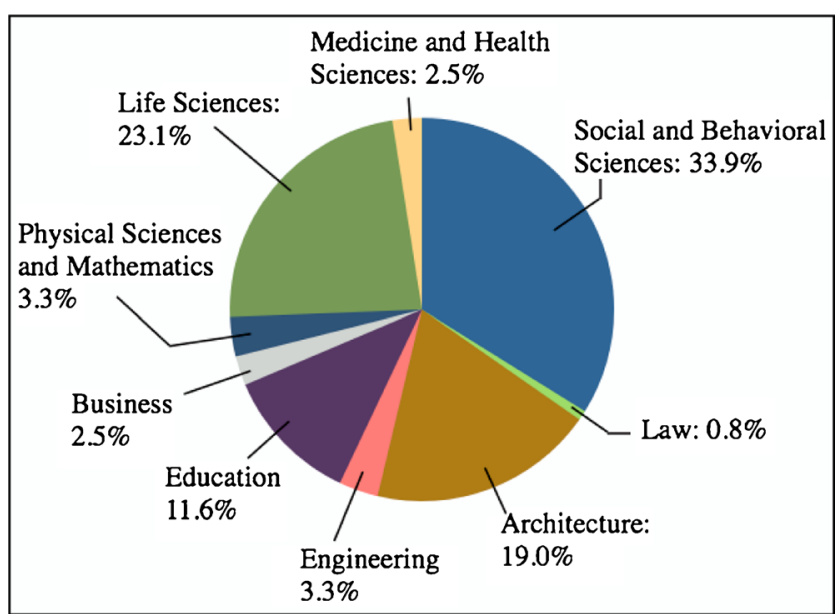

Fig. 5 Distribution of academic disciplines among 122 scholarly publications addressing permaculture. Agroecology and closely related disciplines (grouped within life sciences) represent a minority of scholarly work in permaculture

and book chapter ( 0 to 11$)$. The majority of the permaculture literature is written by non-scientists for a popular audience. Scholarly works, and the subset of peer-reviewed publications within that category, are present as a minority of publications throughout the bibliography, representing 54.3 and $13.9 \%$, respectively. The total share of scholarly and peer-reviewed publications has fluctuated while growing over time (Fig. 4b), from $33 \%$ from 1978 to 1982 to $71 \%$ from 2008 to 2013 .

The 122 scholarly publications in the bibliography are distributed across a broad set of natural and social scientific and professional disciplines (Fig. 5). The most prevalent disciplinary categories, in descending order, are social and behavioral sciences (41), life sciences (28), architecture (23), and education (14).

\subsubsection{Geography of publication and topic}

English-language permaculture literature originates predominantly from the USA, Australia, and the UK (Fig. 6a). The geographic distribution of permaculture writing in the bibliography has become more widely spread over time: $49 \%$ from Oceania (Australia and New Zealand) and $41 \%$ North America in 1978-1987 and $43 \%$ from North America, $34 \%$ Europe, $9 \%$ Oceania, $6 \%$ Africa, and $9 \%$ Asia in 2008-2013.

Sixty percent of the references in the bibliography could be determined to have a geographically specific topic. As in the geographic distribution of the publishing, the topics of permaculture publications were initially confined to the USA and Australia and became more widely distributed over time (Fig. 6b). In 2008-2013 period, 35\% of publications in the bibliography referred to North America, $8 \%$ to Oceania, $22 \%$ to Europe, $18 \%$ to Africa, $6 \%$ to Latin America, $6 \%$ to South Asia, $4 \%$ to East Asia, and $2 \%$ to West Asia.

For references with geographically specific topics, both country of publication and country of topic were classified as "developed" or "developing," using the Human Development Index (Malik 2013). Countries in the "very high human development" category were classified as developed, and countries in the other three categories were classified as developing. Of the 135 references with geographically specific topics, 95 were classified as domestic, with publication and topic taking place in the same country, and 41 classified as international. Of domestic references, 76 were from the developed world and 19 from the developing world. Of the 37 international references published in the developed countries, 17 dealt with topics in developed countries, while 21 examined topics in developing countries. Of the three international references published in the developing world, two examined topics in developed countries, and two examined topics in developing
Fig. 6 Geographic distribution of a place of publication and $\mathbf{b}$ sites discussed as topics in permaculture publications over time

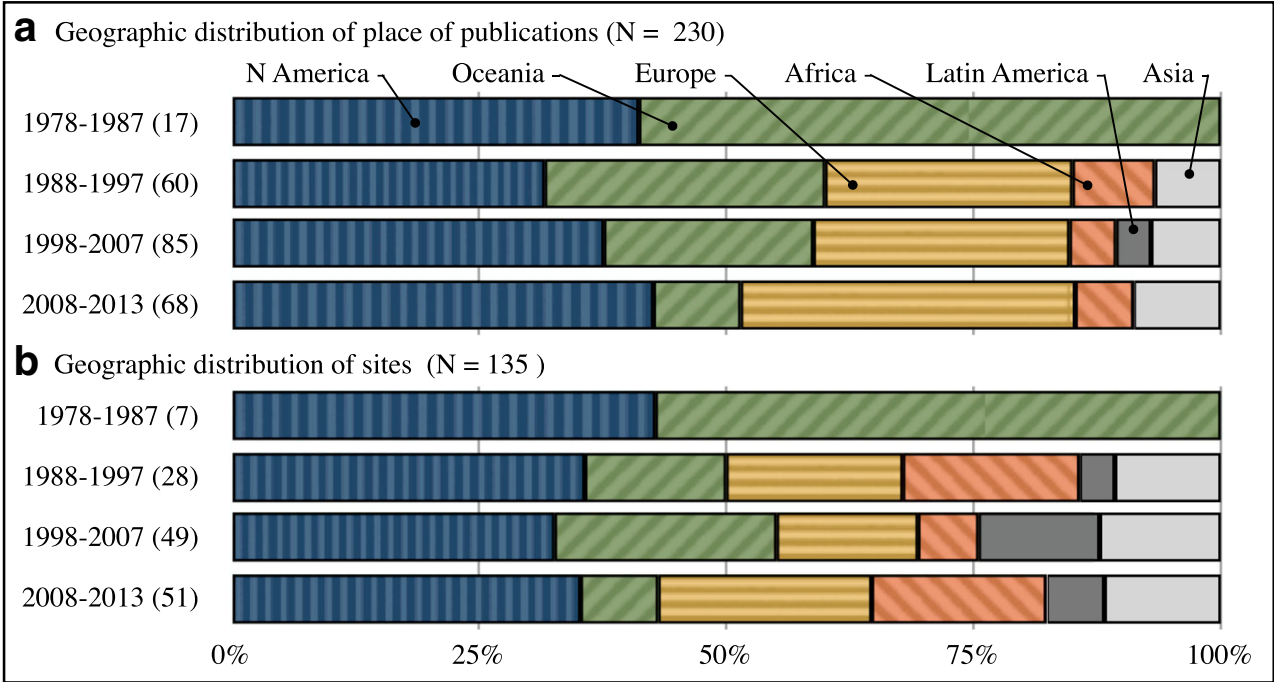




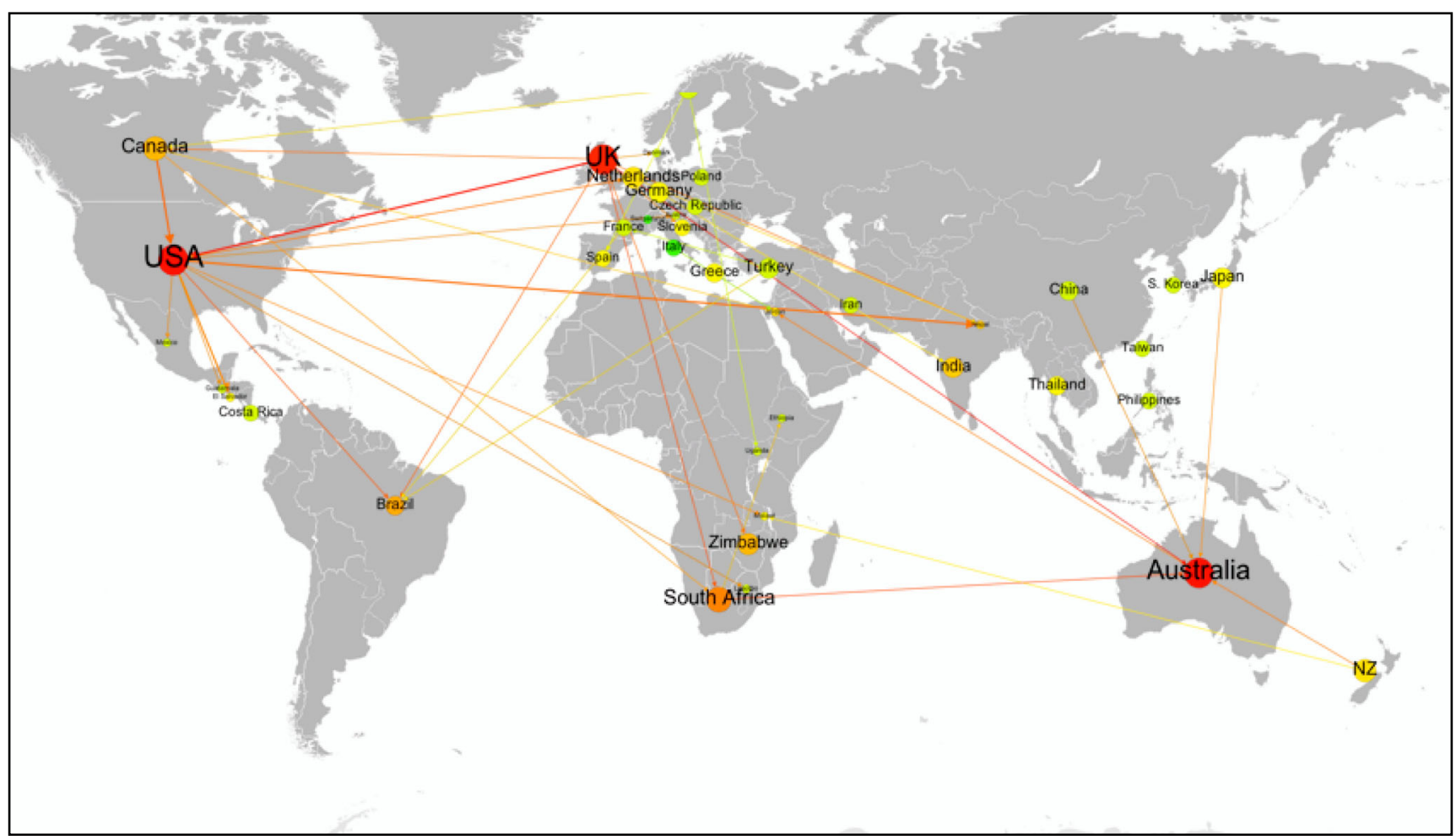

Fig. 7 Network representation of country-by-country relationships between place of publication and place of topic in a 135 permaculture publications. The network illustrates a pattern in which developed countries commonly study developing countries, and the reverse is seldom true. Node size is scaled to indicate the number of

countries - with one of the references dealing with topics in both a developed and a developing country. The country-bycountry relationship between publication and topic is represented as a geographic network in Fig. 7, while the proportional distribution of geographic publication-topic relationships is shown in Fig. 8.

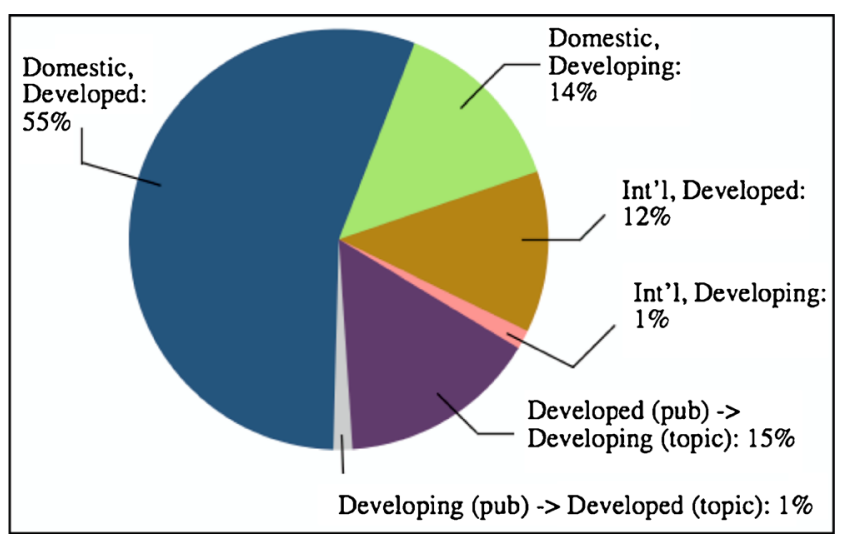

Fig. 8 The proportional distribution of geographic relationships between place of publication and place of topic in 135 references in the permaculture bibliography. "Domestic" describes research that is conducted and published with a single country. "International" describes research that is conducted in one or more countries and published elsewhere publications originating from that country. Node color is a heat map representing number of publications with topics specific to that country, with green indicating few and red indicating many. Links between nodes represent publication/topic relationships, with number of publications indicated by line weight

Queries to multiple language localizations of Google Scholar returned results concentrated in English-language literature. With 7,190 search results, results in English represented $59 \%$ of the total results. In descending rank, returns for other languages were Spanish $(2,190)$, Portuguese $(1,980)$, German (294), French (267), Arabic (95), Japanese (44), and Russian (30). Past research has identified an English-language bias in Google Scholar (Kousha and Thelwall 2008; Neuhaus et al. 2006). Interpretation of these results is therefore limited to the observation that a significant minority of permaculture literature is in languages other than English and is not addressed in this study.

\subsubsection{Concept network}

The network graph produced from the complete series of references, from 1978 to 2013, contained 1,330 edges, with each edge representing the co-occurrence of one word pair. Figure 9 shows the full 100-node network for each time interval and the complete set, illustrating the changing centrality and contextual significance of key terms over time and in aggregate. The modularity algorithm produced six conceptual clusters in the complete sequence, each densely linked to a central term and to each other (Fig. 9d). The central terms, in descending order of importance (by BC), were design, community, 


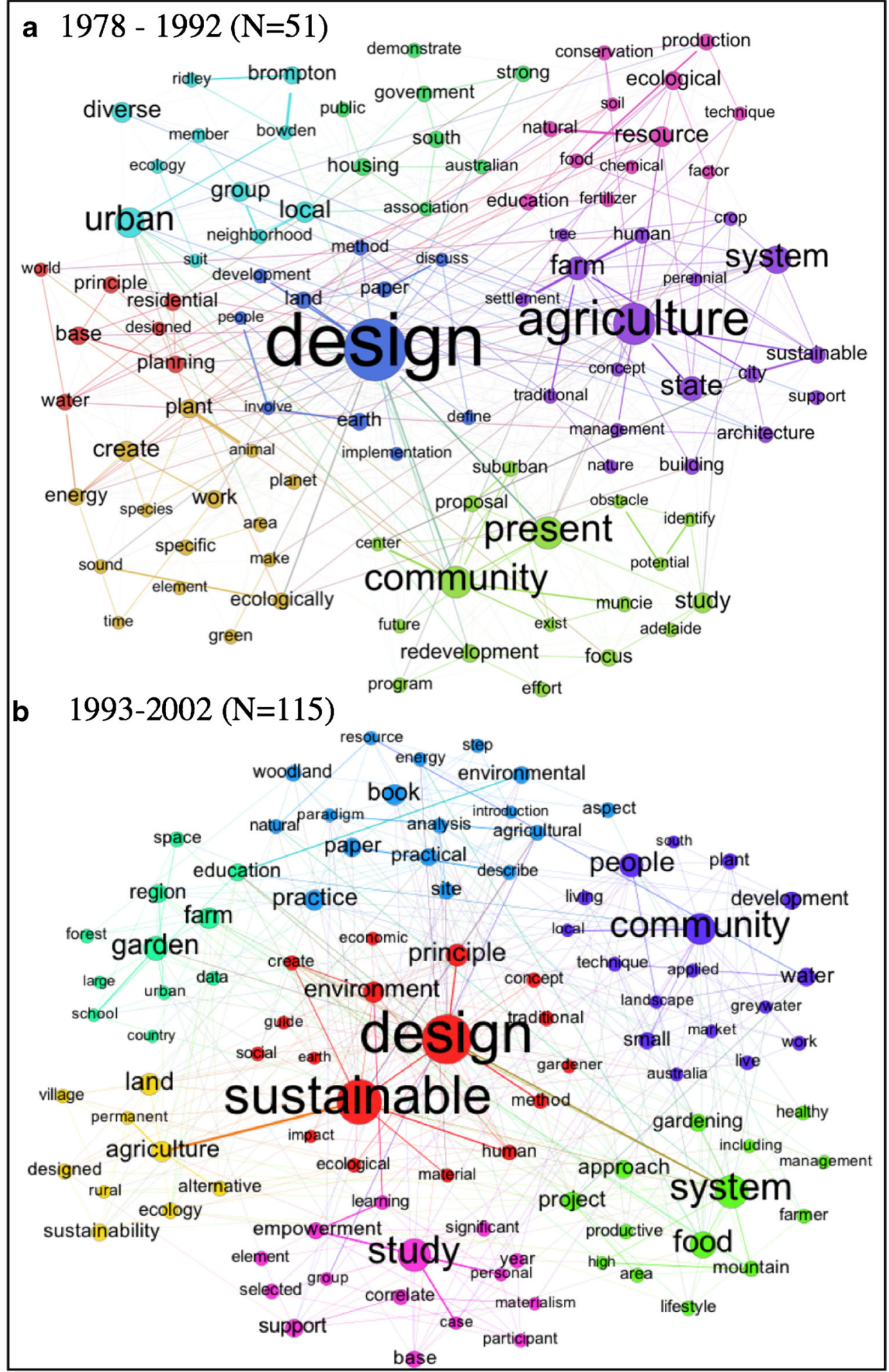

Fig. 9 Concept network maps of keywords from permaculture publications. Node size denotes centrality of concepts, links represent concept co-occurrence, link width represents co-occurrence frequency, and color

sustainable, farm, study, and resource. The network produced from the text of the first sequence of references, from 1978 to 1992, contained 526 edges (Fig. 9a). The modularity algorithm denotes conceptual cluster of tightly interlinked concepts. a Publications 1978-2002 $(N=51)$. b Publications 1993-2002 $(N=115)$. c Publications 2003-2013 $(N=157)$. d Complete series 1978-2013 $(N=230)$

identified eight conceptual clusters, organized around the following terms: design, agriculture, present, urban, resource, create, base, and housing. The five most central clusters in each 


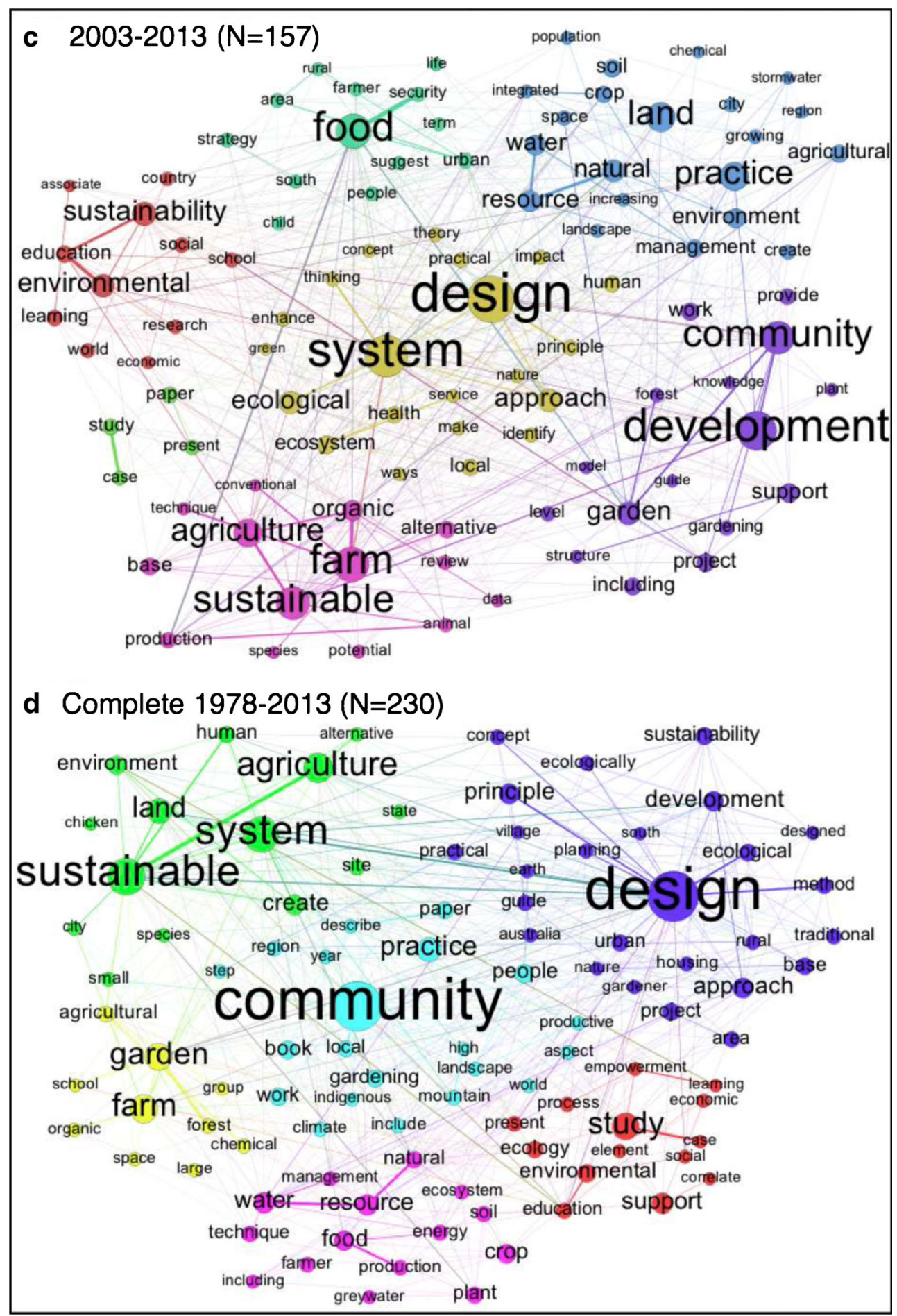

Fig. 9 (continued)

interval, with the five most central terms in each cluster and their BC score, are shown in Table 2. The text extracted from the 1993-2002 references produced a network with 911 edges (Fig. 9b). Seven conceptual clusters were organized around the terms design, community, book, garden, land, study, and system. The 2003-2013 text produced a network with 1467 edges (Fig. 9c). Seven conceptual clusters were identified by the modularity algorithm, organized around the terms design, development, farm, food, land, sustainability, and study.

\subsection{Qualitative review}

In the following section, prominent themes in the permaculture literature are synthesized and assessed in relationship to 
Table 2 Results of concept network analysis of 230 permaculture publications showing five most important clusters (by modularity) and five most important terms in each cluster (by betweenness centrality)

\begin{tabular}{|c|c|c|c|c|c|c|c|c|c|c|}
\hline & Cluster 1 & B.C. & Cluster 2 & B.C. & Cluster 3 & B.C. & Cluster 4 & B.C. & Cluster 5 & B.C \\
\hline \multirow[t]{5}{*}{ 1978-1992 } & Design & 2529 & Agriculture & 1459 & Present & 978 & Urban & 851 & Resource & 376 \\
\hline & Earth & 194 & System & 740 & Community & 956 & Local & 398 & Ecological & 259 \\
\hline & Land & 186 & State & 573 & Study & 337 & Diverse & 364 & Production & 156 \\
\hline & Paper & 149 & Farm & 513 & Redevelopment & 239 & Group & 323 & Education & 155 \\
\hline & Method & 78 & Sustainable & 189 & Focus & 185 & Brompton & 224 & Natural & 112 \\
\hline \multirow[t]{5}{*}{ 1993-2002 } & Design & 1199 & Community & 617 & Book & 273 & Garden & 374 & Land & 297 \\
\hline & Sustainable & 1044 & People & 367 & Practice & 257 & Farm & 290 & Agriculture & 257 \\
\hline & Principle & 314 & Water & 190 & Paper & 199 & Region & 173 & Sustainability & 137 \\
\hline & Environment & 284 & Development & 180 & Practical & 155 & Education & 153 & Ecology & 110 \\
\hline & Human & 96 & Small & 150 & Environmental & 151 & Space & 87 & Alternative & 92 \\
\hline \multirow[t]{5}{*}{ 2003-2013 } & Design & 240 & Development & 192 & Farm & 162 & Food & 161 & Land & 122 \\
\hline & System & 209 & Community & 147 & Sustainable & 149 & Urban & 24 & Practice & 118 \\
\hline & Approach & 74 & Garden & 77 & Agriculture & 112 & Security & 19 & Natural & 72 \\
\hline & Ecological & 73 & Support & 52 & Organic & 60 & Strategy & 19 & Resource & 66 \\
\hline & Ecosystem & 47 & Project & 46 & Base & 38 & People & 16 & Water & 61 \\
\hline \multirow[t]{5}{*}{ 1978-2013 } & Design & 345 & Community & 338 & Sustainable & 218 & Farm & 131 & Study & 128 \\
\hline & Principle & 67 & Practice & 96 & System & 204 & Garden & 124 & Support & 74 \\
\hline & Approach & 66 & People & 50 & Agriculture & 150 & Agricultural & 32 & Environmental & 48 \\
\hline & Complete development & 66 & Book & 49 & Land & 106 & Forest & 16 & Ecology & 37 \\
\hline & Sustainability & 45 & Work & 40 & Create & 65 & Chemical & 14 & Education & 28 \\
\hline
\end{tabular}

contemporary-scientific perspectives on agroecological transition. Results from the quantitative analysis are used to triangulate with and inform qualitative interpretation of permaculture literature. Qualitative results are organized by the levels of the stratified definition of permaculture proposed above.

\subsubsection{Design}

Published definitions of permaculture emphasize its status as a system for the design for human settlements, with an emphasis on productive landscapes (see Section 2.1 above). The concept network analysis reinforces the importance of design as a core component of permaculture, as "design" is the most central concept in each of the three sequential analyses (1978-1992, 1993-2002, 2003-2013) and in the complete sequence (1978-2013).

The permaculture design system utilizes ecological and systems-thinking principles, and spatial reasoning strategies, which are used to analyze site conditions, select practices, and integrate them with site conditions and land use goals (Mollison and Holmgren 1978; Mollison 1988; Holmgren 2004). Figure 10 shows a selection of permaculture principles, grouped into themes and related to principles and design issues in agroecology and related literature. The most distinctive aspects of the permaculture orientation toward agroecosystem design are its emphases on (1) site specificity, including attention to microclimate; (2) interaction between components at multiple scales, from field-scale polycultures to agroecosystem-scale land use diversity; and (3) spatial configuration as a key driver of multiple functions.

From the perspective of permaculture design, crops and land uses should be selected and placed to reflect a fine-grained analysis of in-site heterogeneity, including topography, microclimate, and existing vegetation (Mollison 1988; Jacke and Toensmeier 2005). Microclimate effects, driven by local and regional topography and vegetation, can be leveraged to maximize energy efficiency and identify sites for otherwise marginal crops (Mollison 1988). Ponds and equatorially oriented slopes, structures, and woody vegetation are identified as key sites at which extreme cold temperatures are moderated by thermal mass and heat trapping effects (Mollison 1988; Holzer 2011), which may accommodate less hardy species. The permaculture approach to microclimate is derived from a single influential source first published in 1927 (Geiger and Steward 1950). Discussion of agricultural microclimate in the scientific literature is ongoing (Orlandini et al. 2006).

Land use diversity appears in the permaculture literature in forms that include tightly integrated terrestrial and aquatic 
Fig. 10 A selection of permaculture principles and related principles in agroecology and allied disciplines grouped by themes. With the exception of the principles grouped under the theme of creativity and innovation, permaculture principles have corollaries in the scientific literature, but are articulated at a higher level of abstraction. PDM refers to Mollison (1988), IPM to Mollison and Slay (1997), and PPBS to Holmgren (2004)

\begin{tabular}{|c|c|c|c|}
\hline \multicolumn{2}{|c|}{ Permaculture Principles } & \multicolumn{2}{|c|}{ Agroecology and Related Principles } \\
\hline \multicolumn{4}{|c|}{ DIVERSITY } \\
\hline $\begin{array}{l}\text { Diversity, Plant Stacking \& } \\
\text { Time Stacking (PDM, IPM), } \\
\text { Use and Value Diversity } \\
\text { (PPBS) }\end{array}$ & $\begin{array}{l}\text { Species and gene } \\
\text { (Reijntjes et al. } 1 \\
\text { Contain pests thr } \\
\text { (Malézieux 201 } \\
\text { Maintain landsca } \\
\text { et al. 2008) }\end{array}$ & $\begin{array}{l}\text { 992) } \\
\text { ough complex } \\
\text { 1) } \\
\text { pe heterogenei }\end{array}$ & nmental gradients (Fischer \\
\hline \multicolumn{4}{|c|}{ INTERACTION } \\
\hline $\begin{array}{l}\text { Edge Effects (PDM), Use edges } \\
\text { and value the marginal (PPBS) }\end{array}$ & \multicolumn{3}{|c|}{$\begin{array}{l}\text { Optimize available resources through synergies between "plants, animals, } \\
\text { soil, water, climate and people" (Pretty 1994, Vandermeer 1995) } \\
\text { Use complementary functional traits to ensure production and resilience. } \\
\text { (Malézieux, 2011) }\end{array}$} \\
\hline \multicolumn{2}{|l|}{ Relative location (IPM) } & \multicolumn{2}{|c|}{$\begin{array}{l}\text { Enhance beneficial biological interactions and synergisms } \\
\text { (Reijntjes et al. 1992) }\end{array}$} \\
\hline \multicolumn{2}{|c|}{$\begin{array}{l}\text { Each important function is supported by many } \\
\text { elements (PDM), Each element performs many } \\
\text { functions (PDM) }\end{array}$} & \multicolumn{2}{|c|}{$\begin{array}{l}\text { Enhance recycling of biomass and optimizing nutrient } \\
\text { availability and balancing nutrient flow. (Reinties et al. 1992) }\end{array}$} \\
\hline \multicolumn{4}{|c|}{ CREATIVITY AND INNOVATION } \\
\hline \multicolumn{3}{|l|}{ The problem is the solution (PDM) } & \\
\hline \multicolumn{3}{|c|}{$\begin{array}{l}\text { The yield of a system is theoretically unlimited (or only limited } \\
\text { by the imagination and information of the designer) (PDM) }\end{array}$} & $\begin{array}{l}\text { No corollary } \\
\text { agroecological } \\
\text { principles. }\end{array}$ \\
\hline \multicolumn{4}{|c|}{ Make the least change for the greatest possible effect (PDM) } \\
\hline \multicolumn{4}{|c|}{ ADAPTIVE MANAGEMENT } \\
\hline \multicolumn{2}{|l|}{ Observe and interact (PPBS) } & \multicolumn{2}{|c|}{ Management by experiment (Nudds 1999) } \\
\hline \multicolumn{2}{|c|}{ Apply self-regulation and accept feedback (PPBS } & \multicolumn{2}{|c|}{ Mobilize capacity for inquiry (Blann et al. 2003) } \\
\hline \multicolumn{2}{|c|}{ Creatively use and respond to change (PPBS) } & \multicolumn{2}{|c|}{ Detect and foster novelty (Blann et al. 2003) } \\
\hline \multicolumn{2}{|c|}{ Accelerating succession and evolution (PPBS) } & \multicolumn{2}{|c|}{$\begin{array}{l}\text { Create opportunities for self-organization (Folke et al. } \\
2003 \text { ) }\end{array}$} \\
\hline
\end{tabular}

systems, animal and plant production, and annual and perennial plants (Mollison and Holmgren 1978; Mollison 1988; Bane 2012). This emphasis is consonant with the scientific literature, in which the benefits to productivity generated by synergies between multiple enterprises have been demonstrated repeatedly (Frei and Becker 2005; Jamu and Piedrahita 2002; Berg 2002; Gomiero et al. 1999; Kadir Alsagoff et al. 1990; Talpaz and Tsur 1982; Devendra and Thomas 2002; Rukera et al. 2012; Dey et al. 2010; Pant et al. 2005; Dalsgaard and Oficial 1997). Integration of multiple enterprises has been shown to increase labor efficiency (Dey et al. 2010) and to enhance all dimensions of multifunctionality, including food security and environmental, economic, and social functions (Tipraqsa et al. 2007).

Permaculture's emphasis on configuration is expressed in the Principle of Relative Location and the design tools Zones of Use and Sectors. Hemenway defines relative location in this way "...place the elements of your design in ways that create useful relationships and time-saving connections among all parts" (2009, p. 6). "Sectors" refers to directional forces that impinge on the site from the outside, including sun, wind, water, and wildfire (Mollison and Holmgren 1978; Mollison 1988; Holmgren 2004; Mars 2005; Bell 2005; Hemenway 2009;
Bane 2012). Landscape components can be arranged in order to manage these forces, through exclusion (firebreaks), channeling (windbreaks and water control features), and inclusion (maximizing insolation/minimizing shading for crops and structures). Zones of Use is a concentric model of land use planning intended to maximize farm labor productivity, by siting land uses that require frequent management or use closer to the home or other centers of activity (Mollison and Holmgren 1978; Mollison 1988; Mars 2005; Holmgren 2004; Mars 2005; Bell 2005; Hemenway 2009; Bane 2012).

These principles of agroecosystem configuration, while lacking an explicit parallel discussion in the scientific literature, appear reasonably well supported by existing science. This lack of consideration of spatial relationships in agronomy has been noted by many authors (Cavazza 1996; Veldkamp et al. 2001; Hatfield 2007; Osty 2008; cited in Benoit et al. 2012). Configuration is a nevertheless an implicit issue for land use functions that depend on spatial and topographic relationships, including windbreaks, runoff filtration, habitat provision, nitrogen fixation in polycropping (Ajayi 1987; Fujita et al. 1992), contour cultivation (Tacio 1993; Bunch 2002), and soil and water conservation. At larger scales, configuration is regarded as a 
driver of ecosystem functions (Uuemaa et al. 2012; McNeely and Scherr 2001; Scherr and McNeely 2008) and to a lesser extent cultural functions (Dramstad et al. 2006). While no agroecological literature addresses configuration vis-à-vis labor efficiency, the topic of workplace configuration and its effects on efficiency has a long history and an actively developing literature in other disciplines (Taghavi and Murat 2011; Venkatadri et al. 1997; Becker and Steele 1995; Burbidge 1971).

\subsubsection{Practice}

While permaculture has a distinctive description of the techniques for which it advocates, few if any of those techniques originated from within the permaculture milieu. Permaculture practices are often adopted from or inspired by traditional agroecological systems, as in the case of tropical home gardens and the permaculture "food forest" (Mollison and Holmgren 1978). Natural systems are another source of inspiration, as demonstrated by the guild concept, in which polycultures are designed as analogs to natural functional assemblages (Mollison and Slay 1997). Alternative agricultural techniques, such as the original adoption of the Keyline system of landscape planning, may also be adopted by permaculturists (Mollison and Holmgren 1978; Yeomans 1954). Contemporary examples include the widespread enthusiasm in the permaculture community for aerobic compost tea (Avis 2012) and biochar (Soleil 2012). The "herb spiral," a mound garden design proposed by Mollison for the production of culinary herbs, may be the only practice to have emerged from the permaculture movement itself (Mollison 1988).

In this light, the practical stratum of permaculture might be more productively regarded as a conceptual framework for the evaluation and adoption of practices, rather than a bundle of techniques. Criteria for the evaluation of practice are not articulated explicitly in permaculture principles, but consideration of principles and favored practices suggests two broad conceptual criteria: ecosystem mimicry and system optimization. The criterion of ecosystem mimicry regards the structure and function of unmanaged ecosystems as models and attempts to create highly productive systems with analogous structure and function using species that produce yields for human use (Lefroy 2009; Hatton and Nulsen 1999). The criterion of system optimization does not refer to a model ecosystem, but seeks to identify strategic points of leverage where minimal intervention may enhance performance of desired functions beyond that of naturally occurring systems. Together, these criteria outline an implicit conceptual framework for the evaluation of practices in the permaculture movement and may inform future investigation of these issues.

The design and use of perennial polycultures is a core theme of the permaculture literature (Mollison and Holmgren 1978; Mollison 1988; Mollison and Slay 1997; Jacke and Toensmeier 2005; Hemenway 2009; Frey 2011; Bane 2012) and strongly reflects the criterion of ecosystem mimicry. The design of plant/animal or other multi-kingdom polycultures receives somewhat less attention (Mollison and Holmgren 1978; Holzer 2011; Shepard 2013). Diverse polycultures are valued for resistance to pests and pathogens, resilience to climate variability, diversification of production, and as a prerequisite for facilitative interactions between plants that can reduce the need for material and labor inputs (Mollison and Holmgren 1978; Shepard 2013). Perenniality in cropping species is valued for soil stabilization and conservation functions and for labor efficiency (Mollison and Holmgren 1978; Hemenway 2009).

This view is largely consonant with the emerging scientific perspective on perennial polycultures (Ewel 1999; Lefroy 1999; Jordan and Warner 2010; Malézieux 2012; Picasso et al. 2011; Schoeneberger et al. 2012), as well as the more extensive discussions of field-scale diversity (Francis and Porter 2011; Mt. Pleasant and Burt 2010; Kalame et al. 2011) and perenniality (Jose 2009; Ewel 1986; Cox et al. 2006; Jordan and Warner 2010; Jordan et al. 2007). Permaculture is exceptional in emphasizing the potential of perennial polycultures to replace some portion of annual vegetable crops (Mollison and Holmgren 1978; Toensmeier 2007; Holmgren 2004) and staple crops (Toensmeier 2011). Claims made by some permaculturists concerning the land and labor productivity of complex perennial systems exceed what has been documented in the scientific literature, especially but not exclusively in cold temperate climates (Williams et al. 2001; Williams 2012; cf. Mollison and Slay 1997; Hemenway 2009; Shepard 2013). Dense and complex plantings can have a variety of effects, including the reduction of productivity through above- and below-ground competition for resources, increased pathogen pressure due to lack of air circulation, and increased harvest labor.

The permaculture literature advocates for the intensive management of water throughout the agroecosystem, through an integrated network of surface impoundments, contour ditches, small-scale berms, and basins (Lancaster and Marshall 2008; Holmgren 2004). Redundancy in water storage systems is emphasized, with the priority placed first on soil storage, then surface water impoundments, followed by tank storage (Mollison 1988).

The use of earthworks for water harvesting and control is a global phenomenon in traditional agriculture systems. The productivity and multifunctionality of such systems have been demonstrated across multiple contexts, including arid land agriculture (Evenari et al. 1982; Bruins et al. 1986; Boyd and Gross 2000; Mussery et al. 2013), hillside agriculture in humid zones (Holt-Gimenez 2006), and in aquaculture/ irrigation systems in a wide range of contexts (Prein 2002; Boyd and Gross 2000; Smukler et al. 2010). Despite the frequency with which water harvesting earthworks are addressed in the permaculture literature, discussion of quantitative planning tools is rare (Lancaster and Marshall 2008; Frey 2011). Discussion of the risks posed by dispersive soils, 
which are highly vulnerable to tunnel erosion and thereby to catastrophic failure (Sherard et al. 1976), is entirely absent.

Permaculture literature advocates for attention to new and underutilized crops, consideration of wild relatives of domesticated species, and on-farm breeding of new cultivars (Mollison and Holmgren 1978; Jacke and Toensmeier 2005; Shepard 2013). Informed by the writings of H.T. Odum, the multifunctionality of cropping species is valued over place of origin, and the introduction of nonlocal species is regarded as desirable. In response to internal and external criticism from native plant advocates over the extreme versions of this position (Grayson 2003; Holmgren 2004; Hemenway 2009), many permaculturists have moderated their views on species selection and regard nativity as an important consideration alongside functional criteria (Jacke and Toensmeier 2005; Hemenway 2009). Conflicts on this topic continue, however (Gehron and Webster 2012).

Permaculturists claim that anti-exotic positions are not based in ecological science and that estimates of ecological and economic impacts of introduced species are exaggerated (Jacke and Toensmeier 2005; cf. Clark 2006). At the same time, more complex positions on the native/invasive question are being articulated within the scientific community (Davis 2009). In emerging discussions of novel ecosystems (Seastedt et al. 2008; Buizer et al. 2012) and intervention ecology (Higgs 2012; Hobbs et al. 2011), the value of nativeoriented restoration efforts is questioned in favor of management for ecosystem services. These emerging perspectives on nonnative species and assemblages are consonant with the moderate turn in permaculture and, more broadly, with that aspect of the permaculture worldview that positions humans as ecosystem managers within, rather than separate from, nature (see Section 4.2.4 below).

\subsubsection{Movement}

The permaculture movement communicates a distinctive worldview to new and potential participants and disseminates elements of practice and design through networks of practitioners and small institutes. The role of such popular movements and networks in advancing agroecological transition through the mobilization of social and political support is increasingly acknowledged in the peer-reviewed literature (Nelson et al. 2009; Ferguson and Morales 2010; Rosset et al. 2011; Altieri and Toledo 2011).

The growth and dissemination of permaculture is built on two basic patterns: a widely dispersed network of "itinerant teachers" (Mollison 2003) and local/regional organizing based around "bioregional" cultures and the development of alternative economic and social institutions (Mollison 1988; Holmgren 2004). The bioregional organizing aspect of permaculture promotes ideas associated with alternative institutions, and realized projects include gardening organizations, farms, demonstration sites, credit unions, multi-issue community organizations, numerous periodicals, campus greening and local food initiatives, and a variety of accredited and unaccredited institutions of higher learning (Ochalla 2004; Grayson 2010a; Battisti 2008; Harb 2011). The concept network analysis reflects the importance of concepts of community and sociality in the permaculture literature. The concepts "community" and "development" are present and closely related in all three sequential analyses, becoming more central over time. In the complete sequence (1978-2013), the centrality of community is nearly equal to design.

The focus on itinerant teachers has distinctively marked permaculture's development with high-profile professionals"permaculture celebrities" - whose international travel is organized around invitations to teach courses (organized by local conveners) and by employment opportunities as designers and consultants (Mollison 2003). The focus on traveling teachers likely played a significant role in the rapid expansion of the movement (Grayson 2010a). The permaculture movement, however, displays significantly less organization and institutionalization than other international agroecological movements, e.g., La Via Campesina, Campesino à Campesino, or International Federation of Agricultural Producers (Borras et al. 2008; Rosset et al. 2011; MartínezTorres and Rosset 2010; q.v. Grayson 2010b). This lack makes the coordination of action beyond the immediate community scale difficult or impossible and thus limits the potential for mobilization of political support for diversified farmers (de Molina 2012).

The distribution of permaculture publications has transitioned from sharply delimited to relatively diverse. The initial geographic limitation can be traced to the Englishlanguage origin of the permaculture framework in Australia. Due to the English-language constraint of this study, results can be assumed to skew in the direction of publications from Oceania, the UK, and the USA, and that actual publishing is more geographically diverse than reported here. The geographic relationships between place of publication and place of topic, however, show a consistently low level of diversity that parallels the "coloniality of knowledge" described in the agroecological literature (Gómez et al. 2013), wherein writings on both the developed and the developing world are published in highly developed countries, and very few studies of developed countries are published in the developing world.

\subsubsection{Worldview}

The relevance of permaculture to agroecological transition is driven in part by the worldview disseminated by the movement. The emerging focus in the agroecological literature on the "worldview challenge" acknowledges the importance of knowledge and beliefs for transition (Jordan et al. 2008; Berkes et al. 2000). Any agricultural system is not only a set 
of practices, but also a framework of knowledge about how and when to apply any given technique, a belief system that proposes a mechanism of action and a normative proposal about what practices and land use goals are desirable and why (Norgaard 1984; Berkes et al. 2000). Agroecological transition requires not only new techniques, but new stories to provide context and meaning for those techniques (Sanford 2011).

Key elements of the permaculture worldview include ideas about human-environment relations, a populist orientation to practice, and a model of social change. The permaculture literature expresses a theory of human-environment relations that highlights the positive role of humans in the landscape, as ecosystem managers. This perspective is expressed through a literature-wide insistence on the need for holistic planning and design and an optimistic assessment of what these styles of management can achieve. This perspective on human-environment relations cuts against the grain of the dualistic worldviews of both growth-oriented development and preservationoriented conservation, each of which describe a fundamental conflict between the needs of society and those of nature (Pálsson 1996; Strongman 2012). At the core of the permaculture worldview is the idea that-with the application of ecologically informed holistic planning and design-humans can meet their needs while increasing ecosystem health (this author, quoted in Toensmeier and Bates 2013).

The populist orientation in the permaculture literature repeatedly (though not uniformly) portrays the solutions to environmental and social crises as both simple and known. Academic institutions and researchers are common topics of criticism for conservatism, the plodding pace of change, failure of vision, and for being beholden to corporate interests (Mollison and Holmgren 1978; Mollison 1979; Holmgren 2004; Holzer 2011; Shepard 2013). Mollison and Holmgren claim that permaculture requires only the recombination of existing knowledge, rather than the generation of new knowledge (Mollison and Holmgren 1978), and one of Mollison's most widely quoted aphorisms is "Though the problems of the world are increasingly complex, the solutions remain embarrassingly simple" (Permaculture Institute 2013). Some recent permaculture authors, in contrast, do present their proposals as hypotheses in need of testing (Jacke and Toensmeier 2005).

The emphasis on practice over theory, and on networks of practitioners, is reflected in a model of social change that emphasizes individual personal responsibility and voluntary action and a relative lack of interest in influencing policy or large institutions (Mollison and Holmgren 1978; Holmgren 2004; Shepard 2013). Mollison proposes a "prime directive" that states "The only ethical decision is to take responsibility for our own existence and that of our children's" (1988, p. 1). This focus on individuals as the locus of change is moderated by principles of cooperation at the level of the community or bioregion (Mollison 1988; Holmgren 2004). In a quotation that captures both the simplicity and the scale of permaculture's model of change, prominent permaculturist Geoff Lawton uses the tagline "All the world's problems can be solved in a garden" (Lawton 2008).

\section{Synthesis}

Integrating quantitative and qualitative review methods to evaluate the English-language permaculture literature, this study establishes a foundation for future dialog between permaculture and agroecology. The integrated analysis of popular and scientific literature is necessitated by the nature of the permaculture literature and entails the adaptation of established review methods. This mixed-methods approach is useful for addressing the challenges of a large and heterogeneous field divided between scientific and popular literature. Triangulation between qualitative and quantitative analysis supports the synthesis of broad generalizations about the permaculture literature, while the limits to these generalizations are also identified. Highlighting the limitations in our knowledge of permaculture will help outline directions for future research.

By developing the first critical scientific review of the permaculture literature, organized around a novel stratified definition, this project contributes to the understanding of an agroecological movement which has received very little rigorous scrutiny. By using the concept of "agroecological transition" as an analytical frame, this study moves beyond the fragmentary and often one-sided analyses that characterize previous discussion of permaculture and supports a balanced and holistic evaluation of biophysical and social factors. Figure 11 expands the stratified definition offered above (Fig. 3) to incorporate themes and patterns revealed in this project.

This review supports the idea that permaculture has contributions to offer the project of agroecological transition. Principles and themes in the permaculture literature largely complement, and sometimes provide useful extension of, those found in the agroecology literature. The permaculture approach to agroecosystem design and practice offers a distinctive perspective and emphasis on the value and potential of perennial crop species, polyculture, integrated water management, and the importance of agroecosystem configuration. Systematic and bibliometric analyses reveal an increasing diversity in geography over time. The movement is mobilizing diverse forms of social support for sustainability, in geographically diverse locations, although there is less evidence for direct impact on agroecological transition. The value of permaculture's contributions remains constrained by several significant factors in the culture of the movement. 
Fig. 11 Stratified definition of permaculture, expanded to incorporate distinctive themes relevant to agroecological transition appearing in the permaculture literature, as addressed in this survey

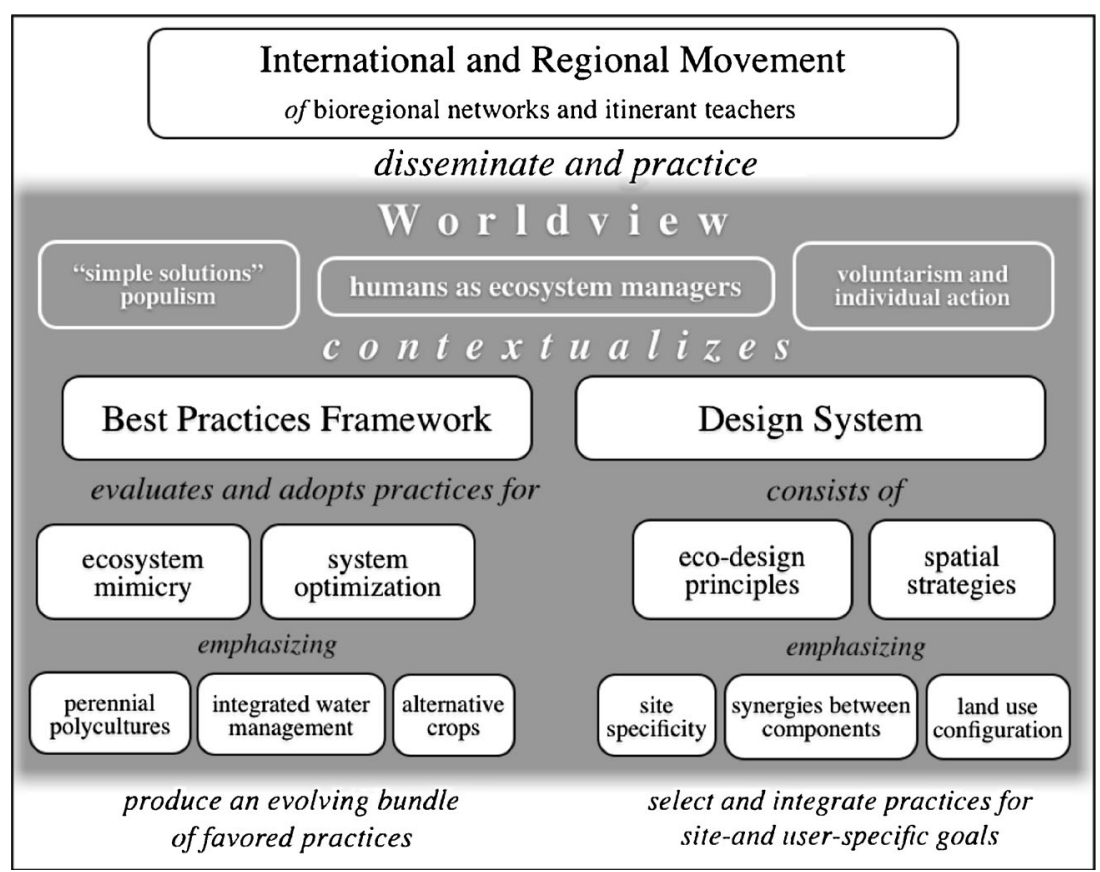

\subsection{Substantiation and scholarship}

\subsubsection{Overreaching claims}

Permaculture has frequently been the target of criticism for overreaching and oversimplifying claims about the achievements and state of knowledge represented by the permaculture system. The tendency towards overreaching and oversimplification is encapsulated in the notion that humanity already possesses all the knowledge necessary to replace current land use with permaculture systems in all contexts (Mollison and Slay 1997, p. 1) and that the process of redesigning is itself straightforward. In the absence of reliable data to support these proposals, permaculturists often rely on anecdotal report and sweeping extrapolation from ecological principles.

Permaculturists have been accused repeatedly of inflating both the land and labor productivity of complex polycultures and perennial systems. The derivation of production figures in Mollison's canonical Permaculture: A Designer's Manual (1988), as in most permaculture publications, is unreferenced and unknown. Claims of productivity are sometimes justified through misreading or misapplication of ecological principles (Romanowski 2007). One common example is the conflation of net primary production with the production of edible tissue (Williams et al. 2001; Williams 2012; cf. Mollison 1988, Hemenway 2009; Jacke and Toensmeier 2005; Shepard 2013). While forest ecosystems are among the highest in NPP, perennial plants allocate a higher percentage of photosynthetic activity to structure than annuals and therefore have a slimmer margin for export as edible tissue (Jordan 1971; Malézieux 2012), rendering the comparison of potential yields a complex empirical question rather than a simple maxim. Anecdotal reports on the productivity of multi-strata silvopasture integrated with multi-species rotational grazing are promising but unsubstantiated (Shepard 2013) and point the way toward future research. An additional example of the misapplication of ecological principles is the claim that complex shapes in fields, garden beds, and ponds will increase productivity (Mars 2005; Hemenway 2009; Bell 2005). This claim is based on the permaculture principle of edge effects that was itself extrapolated from the ecological characteristics of ecotones and anecdotal reports of edge effects in grain cropping systems (Mollison and Holmgren 1978; Mollison 1988). Some recent permaculture publications, however, have provided more complex and empirical descriptions of edge effects (Holmgren 2004; Jacke and Toensmeier 2006).

The permaculture literature often downplays or ignores the risks and challenges of planning and maintaining highly complex agroecosystems. Permaculture has been criticized for the increased harvest labor associated with structural complexity (Reich 2010). Planning for diversified enterprises is complex and challenging, and while there are signs of change, currently the majority of planning and support resources are oriented toward simple non-diversified farming operations (McIntyre et al. 2009). Farmers utilizing complex polycultures and diverse enterprises will likely face significant hurdles to attain economic viability. In this, however, permaculture does not differ from other approaches to farm diversification and integration (Morris and Winter 1999; Tipraqsa et al. 2007; Amekawa et al. 2010; Kremen et al. 2012).

The inattention to complexity and risk in the permaculture literature may have serious consequences on and beyond the 
farm. In the case of water management, modification of existing natural grade and site hydrology may result in flooding, increased erosion, and loss of topsoil. For extensive and interlinked modifications that include impoundments, the risk is proportionally greater - both to the landowner's investment in earthmoving and in potential damage to structures and fields downslope. The potential impacts of extensive earthworks on catchment-scale hydrological processes are complex and will likely include consequences for both upstream and downstream landscapes and communities (Rockström et al. 2010).

\subsubsection{Isolation from science}

This study underscores the observation that, although permaculture emerged from an academic collaboration between professor (Mollison) and student (Holmgren), the movement has been largely isolated from scientific research. Most permaculture texts do not refer to contemporary scientific research (Scott 2010; Chalker-Scott 2010). In a reading list for advanced study of permaculture, revised most recently in 2003, the average publication date of the 11 titles (excluding Mollison's own work) was 1964 and the most recent was 1985 (Mollison 2003). Permaculture's lack of reference to contemporary science holds true even for fields that would seem to have the most bearing on the core premises and proposals of permaculture, such as agroecology and agroforestry. The permaculture literature assigns the blame for this isolation on the inability of scientists and institutions to comprehend or appreciate the radical proposals put forth by permaculture (Mollison and Holmgren 1978; Mollison 1979, 1988; Holmgren 2004; Shepard 2013). The counter-example of the Land Institute, however, and its project of replacing annual staple crops with perennial grains in diverse prairie-mimic polycultures illustrates the way in which radical proposals may be grounded in rigorous empirical science and be well received by the scientific community (DeHaan et al. 2005; Cox et al. 2006; Glover et al. 2010).

While the increase in scholarly publications shown by the bibliometric analysis suggests that the situation may be changing, there are cumulative effects from decades of relative isolation that go beyond the lack of research on permaculture systems. These include the lack of awareness, in the permaculture literature, of contemporary developments in relevant science, the accompanying persistence of idiosyncratic or misleading terminology, and the potential for influence of pseudo-scientific theories. The idiosyncratic use of scientific and scientific-sounding terms, together with permaculture's heterodox stance on issues such as species selection, has persuaded some writers to label permaculture as a pseudoscience (Chalker-Scott 2010).

An example of idiosyncratic use of scientific terms in permaculture is the use of the term "guild" to refer to complementary, mutually beneficial plant assemblages (Mollison and Slay 1997; Holmgren 2004; Bell 2005; Burnett and Strawbridge
2008; Hemenway 2009; Bane 2012). This is nearly opposite of its scientific meaning, which describes a group of plants that occupy a similar niche and make use of the same resources - in other words, plants that are especially unsuited to being grown in a polyculture assemblage (Simberloff and Dayan 1991). Permaculture discussions of polyculture design also typically make use of the term "dynamic accumulators" to refer to plants that draw nutrients from the subsoil and concentrate them in the topsoil, thereby simultaneously benefiting nearby plants (Whitefield 2004; Jacke and Toensmeier 2005; Bell 2005; Jacke and Toensmeier 2006; Hemenway 2009). The term does not appear in scientific literature, and its use is regarded as evidence that permaculture is pseudo-scientific (Chalker-Scott 2010). As there is ample support in the ecological literature for the importance of plant processes in determining the vertical distribution of nutrients in the soil column (Jobbágy and Jackson 2004; Callaway 1995; Porder and Chadwick 2009), the less pejorative "folk science" may be a more appropriate label (q.v. Berkes 2008).

\subsubsection{Permaculture scholarship}

Even within the growing scholarly sector, most authors are not from disciplines with close ties to agroecology. Scholarly work on permaculture from more closely related disciplines is often marked by sparse citations of relevant scientific literature. The work of Jacke and Toensmeier (2005) constitutes an exception to this pattern. The first volume of their twovolume work on edible forest gardening is devoted entirely to a review of relevant scientific theory, and both volumes draw heavily on the scientific literature.

Scholarship has historically comprised a marginal but diverse sector within permaculture. Concepts associated with scholarship, including "study," "education," "correlate," and "paper," have had a consistent presence in the literature but have never approached the first or second quartile of centrality. The high level of abstraction at which the permaculture design system is articulated appears to support engagement with topics beyond the strictly biophysical and agricultural and to invite investigation from scholars from a diverse set of analytical and methodological traditions. While currently marginal, the historical isolation of permaculture from scientific research may be diminishing - particularly if the significant growth in graduate theses documented in this review continues.

\subsection{Limitations of this study}

This study is limited by its restriction to English-language literature. Both qualitative and quantitative analyses are likely skewed in unknown ways by this restriction. Follow-up reviews of permaculture literature in multiple languages should be carried out at the earliest opportunity. Additionally, this study addresses only those aspects of permaculture most pertinent to 
the question of agroecological transition. This is a necessary constraint, with the stipulation that this review should therefore not be read as a comprehensive assessment of the breadth of permaculture literature, as we are not concerned here with numerous topics discussed in that literature, including forest management, building techniques, settlement planning, and so on. Finally, by restricting this review to publications appearing in databases of scientific research, scholarly and technical literature are likely overrepresented in the bibliography and therefore represent a smaller proportion of the total English-language permaculture literature than is represented here.

\subsection{Future directions}

Permaculture's integrated approach to agroecosystem design offers tools and suggests directions for future research. Until recently, there was no parallel discussion in the scientific literature on farm design, which has largely consisted of computer modeling and simulation that are not well suited to complex diversified operations (Sterk et al. 2006) and do not deal substantively with spatial relationships (Martin et al. 2012). The importance of the abundance and distribution of land uses to farm sustainability, and interest in the development of tools to support spatially explicit farm design processes, has only recently entered the scientific literature (Benoit et al. 2012; Lovell et al. 2010; Sterk et al. 2006) and remains largely exploratory.

Themes for investigation identified in this study include agroecosystem design and configuration, perenniality, and diversity. The role of agroecosystem configuration in driving multiple functions, including environmental functions, labor productivity, and land productivity, is a pressing question that has bearing for all diversified farming systems. The development of design approaches to agroecosystem planning could make valuable contributions in the context of farmer-oriented participatory research. The role of principles and pattern (including natural pattern and pattern languages) in supporting site analysis and design solutions are also promising avenues of investigation. The farmer-friendly articulation of the permaculture principles and the incorporation of principles meant to stimulate creative problem solving (e.g. "The Problem is the Solution") represent a potential contribution to participatory research and development.

Permaculture's distinctive aggressive emphases on perenniality and diversity are useful provocations to supporters and researchers of diversified production systems. The potential of diverse perennial systems, such as rotational silvopasture systems (Shepard 2013), for the production of staple and complementary crops in temperate zones has recently informed empirical field trials at a major agricultural research university in the USA (WPP Research 2013) and should inspire more.

Permaculture continues to be hampered by overreaching and oversimplifying claims made by advocates. The portrayal of the scientific community as homogenous, too slow, or altogether reactionary helped create a charismatic populist message in the early years of permaculture. While this approach may have been important in rapidly disseminating permaculture and creating an international movement, it now limits the value of permaculture by rendering it more difficult to interface with the larger community of researchers, institutions, and movements, addressing the project of agroecological transition. It is important to note that sciences that were in their infancy at the time of permaculture's origins have now matured and begun to exert increasing influence and that some of these sciences have a high degree of consonance with permaculture's aims and worldview (e.g., agroecology, agroforestry, ecological engineering). The value of permaculture for agroecological transition can only be enhanced by building dialog and exchange with related disciplines.

The relevance of permaculture to agroecological transition is not limited to issues of design and practice. The increasing interest within the agroecological literature on issues of worldview and popular movements supports further investigation of the social aspects of permaculture. Like other agroecological movements, the spread of permaculture in the absence of significant scientific or institutional support points to the importance of beliefs and norms for the adoption of new agroecological frameworks. Permaculture's optimistic focus on holistic and positive action, on personal responsibility, and on the simplicity of needed solutions is empowering for participants (Smith 2002) and is likely a significant driver of the spread of the movement. However, the portrayal of agroecological transition as something that individuals can contribute to, using simple techniques at home, is a double-edged sword. While prioritizing the perspectives and capacities of land users is important, it may also run the risk of depoliticizing aspects of agroecological transition that are fundamentally political (de Molina 2012; Lovell et al. 2010; Rosset and Martínez-Torres 2012) and trivializing the complexity of socioecological processes and struggles. Investigating the conditions under which participation in the permaculture movement informs changes in agricultural practice, and mobilizes social and political support for diversified farming systems, will contribute to the scientific and practical understanding of agroecological transition.

While the overlap in topic and orientation between permaculture and agroecology is clear, assessing the value of permaculture to the task of agroecological transition continues to be confounded by gaps in our knowledge of the impacts of permaculture design and practice. This broad overview of the permaculture literature is not exhaustive and points toward the need for further and more detailed systematic review of practices advocated for in permaculture literature. Opportunities for collaborative research and documentation of permaculture sites, and field trials of distinctive practices not reflected in the agroecological literature, should be vigorously pursued. The impacts of the design and practice aspects of permaculture should be assessed through comparative analysis of 
agroecosystems where the design framework has been implemented, focusing on (1) spatio-functional analysis to assess the role of configuration in determining production, ecological, and production functions (cf. Lovell et al. 2010) and (2) livelihood-based research, including quality of life, to investigate the diversity of benefits and motivations for permaculture producers.

\section{Conclusion}

The project of agroecological transition is pressing and complex. Agroecologists must continue to look outside the boundaries of their discipline in order to evaluate the resources and opportunities presented by other disciplines and movements in supporting that transition. Permaculture offers distinctive resources for that project, but further research, development, and collaboration is required to assess and realize its full value. This review provides a needed foundation and framework for that task.

If it were possible to distill the agroecological content of the permaculture literature into a single thesis, it might appear in this way: With systematic site design, emphasizing diversity at multiple scales, integrated water management, and access to global germplasm, we can increase the productivity demonstrated by heritage agroecosystems - especially labor productivity - while retaining their most desirable attributes of sustainability and multifunctionality. This thesis is highly relevant to the task of agroecological transition and begs numerous questions that can only be answered through a dedicated research program. It also suggests the beginnings of a framework for the further integration of different sectors of agroecological research, through the lens of integrated design of agroecosystems. This view toward integration and application may be the most significant benefit offered to agroecology by the rigorous analysis of permaculture theory and practice.

Open Access This article is distributed under the terms of the Creative Commons Attribution License which permits any use, distribution, and reproduction in any medium, provided the original author(s) and the source are credited.

\section{References}

Ajayi MT (1987) Effects of spacing/number of plants per stand and fertilizer placement on performance of two maize varieties intercropped with cowpea in the forest zone of Nigeria. Ghana J Agric Sci 20:39-46

Alexander C (1977) A pattern language: towns, buildings, construction. Oxford University Press, New York

Altieri MA (2004) Linking ecologists and traditional farmers in the search for sustainable agriculture. Front Ecol Environ 2:35-42. doi:10. 1890/1540-9295(2004)002[0035:LEATFI]2.0.CO;2

Altieri MA, Toledo VM (2011) The agroecological revolution in Latin America: rescuing nature, ensuring food sovereignty and empowering peasants. J Peasant Stud 38:587-612. doi:10.1080/03066150.2011. 582947

Amekawa Y, Sseguya H, Onzere S, Carranza I (2010) Delineating the multifunctional role of agroecological practices: toward sustainable livelihoods for smallholder farmers in developing countries. J Sustain Agric 34:202-228. doi:10.1080/10440040903433079

Avis R (2012) Compost teas and extracts: brewin' and bubblin' basics. In: Permac. Res. Inst. - Permac. Forums Courses Inf. News. http:// permaculturenews.org/2012/07/11/compost-teas-and-extractsbrewin-and-bubblin-basics/. Accessed 28 May 2013

Bane P (2012) The permaculture handbook: garden farming for town and country. New Society, New York

Bastian M, Heymann S, Jacomy M (2009) Gephi: an open source software for exploring and manipulating networks. Int. AAAI Conf. Weblogs Soc. Media 2009

Battisti BT (2008) Permaculture in higher education: teaching sustainability through action learning. University of California Davis

Bavec M, Mlakar SG, Rozman C, Pazek K, Bavec F (2009) Sustainable agriculture based on integrated and organic guidelines: understanding terms - the case of Slovenian development and strategy. Outlook Agric 38:89-95. doi:10.5367/000000009787762824

Becker FD, Steele F (1995) Workplace by design: mapping the highperformance workscape. Jossey-Bass, New York

Bell G (2005) The permaculture garden. Chelsea Green, White River Junction

Benoit M, Rizzo D, Marraccini E, Moonen AC, Galli M, Lardon S, Rapey H, Thenail C, Bonari E (2012) Landscape agronomy: a new field for addressing agricultural landscape dynamics. Landsc Ecol 27:1385-1394. doi:10.1007/s10980-012-9802-8

bepress (2010) Disciplines: introduction to digital commons three-tiered taxonomy of academic disciplines. In: Digital Commons Reference Material and User Guides. http://digitalcommons.bepress.com/ reference/9. Accessed 15 Mar 2013

Berg H (2002) Rice monoculture and integrated rice-fish farming in the Mekong Delta, Vietnam - economic and ecological considerations. Ecol Econ 41:95-107. doi:10.1016/S0921-8009(02)00027-7

Berkes F (2008) Sacred ecology. Routledge, New York

Berkes F, Colding J, Folke C (2000) Rediscovery of traditional ecological knowledge as adaptive management. Ecol Appl 10:1251-1262. doi: 10.1890/1051-0761(2000)010[1251:ROTEKA]2.0.CO;2

Blann K, Light S, Musumeci JA (2003) Facing the adaptive challenge: practitioners insights from negotiating resource crises in Minnesota. In: Berkes F, Colding J, Folke C (eds) Navigating dynamic socioecological systems: building resilience for complexity and change. Cambridge University Press, Cambridge, pp 210-240

Borras SM Jr, Edelman M, Kay C (2008) Transnational agrarian movements: origins and politics, campaigns and impact. J Agrar Chang 8: 169-204. doi:10.1111/j.1471-0366.2008.00167.x

Boyd CE, Gross A (2000) Water use and conservation for inland aquaculture ponds. Fish Manag Ecol 7:55-63. doi:10.1046/j.1365-2400. 2000.00181.x

Brandes U (2001) A faster algorithm for betweenness centrality*. J Math Sociol 25:163-177. doi:10.1080/0022250X.2001.9990249

Bruins HJ, Evenari M, Nessler U (1986) Rainwater-harvesting agriculture for food production in arid zones: the challenge of the African famine. Appl Geogr 6:13-32. doi:10.1016/0143-6228(86)90026-3

Buizer M, Kurz T, Ruthrof K (2012) Understanding restoration volunteering in a context of environmental change: in pursuit of novel ecosystems or historical analogues? Hum Ecol 40(1): 153. doi: 10.1007/s10745-011-9445-4

Bunch R (2002) Increasing productivity through agroecological approaches in Central America: experiences from hillside agriculture. In: Uphoff $\mathrm{N}$ (ed) Agroecological innovations increasing food production with participatory development. Earthscan, London, pp 162-172

Burbidge JL (1971) Production flow analysis. Prod Eng 50:139-152

Burnett G, Strawbridge B (2008) Permaculture: a beginner's guide, 2nd ed. Spiralseed, Westcliff 
Callaway RM (1995) Positive interactions among plants. Bot Rev 61: 306-349. doi:10.1007/BF02912621

Cavazza L (1996) Agronomia aziendale e agronomia del territorio. Riv Agron 30:310-319

Chalker-Scott L (2010) Permaculture - my final thoughts. In: Gard. Profr.-WSU Ext. https://sharepoint.cahnrs.wsu.edu/blogs/ urbanhort/archive/2010/05/26/permaculture-my-final-thoughts. aspx. Accessed 29 May 2013

Clark H (2006) Invasion biology: critique of a psuedoscience (book review). W N Am Nat 66:537-539

Clark W (1975) Energy for survival: the alternative to extinction. Anchor, New York

Cole JP (1981) The development gap: a spatial analysis of world poverty and inequality. Wiley, New York

Cox TS, Glover JD, Van Tassel DL, Cox CM, DeHAAN LEER (2006) Prospects for developing perennial grain crops. Bioscience 56:649659. doi:10.1641/0006-3568(2006)56[649:PFDPGC]2.0.CO;2

Dahlberg KA (1979) Beyond the green revolution. The ecology and politics of global agricultural development. Plenum, New York

Dalsgaard JPT, Oficial RT (1997) A quantitative approach for assessing the productive performance and ecological contributions of smallholder farms. Agric Syst 55:503-533. doi:10.1016/ S0308-521X(97)00022-X

Davis MA (2009) Invasion biology. Oxford University Press, Oxford

De Molina MG (2012) Agroecology and politics. How to get sustainability? About the necessity for a political agroecology. Agro Ecol Sustain Food Syst 37:45-59. doi:10.1080/10440046.2012.705810

De Schutter O (2010) Report submitted by the special rapporteur on the right to food. United Nations Human Rights Council

De Steiguer JE (2006) The origins of modern environmental thought. University of Arizona Press, Tucson

Deb S, Barbhuiya AR, Arunachalam A, Arunachalam K (2008) Ecological analysis of traditional agroforest and tropical forest in the foothills of Indian eastern Himalaya: vegetation, soil and microbial biomass. Trop Ecol 49:73-78

DeHaan LR, Van Tassel DL, Cox TS (2005) Perennial grain crops: a synthesis of ecology and plant breeding. Renew Agric Food Syst 20: 5-14. doi:10.1079/RAF200496

Devendra D, Thomas T (2002) Crop-animal interactions in mixed farming systems in Asia. Agric Syst 71:27-40. doi:10.1016/S0308521X(01)00034-8

Dey MM, Paraguas FJ, Kambewa P, Pemsl DE (2010) The impact of integrated aquaculture-agriculture on small-scale farms in Southern Malawi. Agric Econ 41:67-79. doi:10.1111/j.1574-0862.2009.00426.x

Dramstad D, Tveit MS, Fjellstad F, Fry F (2006) Relationships between visual landscape preferences and map-based indicators of landscape structure. Landsc Urban Plan 78:465-474. doi:10.1016/j. landurbplan.2005.12.006

Evenari M, Shanan L, Tadmor N (1982) The Negev: the challenge of a desert. Harvard University Press, Cambridge

Ewel JJ (1986) Designing agricultural ecosystems for the humid tropics. Annu Rev Ecol Syst 17:245-271. doi: 10.1146/annurev.es.17. 110186.001333

Ewel JJ (1999) Natural systems as models for the design of sustainable systems of land use. Agrofor Syst 45:1-21. doi:10.1023/A:1006219721151

Ferguson BG, Morales H (2010) Latin American agroecologists build a powerful scientific and social movement. J Sustain Agric 34:339 341. doi:10.1080/10440041003680049

Fernandez M, Goodall K, Olson M, Mendez E (2012) Agroecology and alternative agrifood movements in the United States: towards a sustainable agrifood system. Agro Ecol Sustain Food Syst 37:115126. doi:10.1080/10440046.2012.735633

Fischer J, Lindenmayer DB, Manning AD (2008) Biodiversity, ecosystem function, and resilience: ten guiding principles for commodity production landscapes. 4(2):80-86, doi: 10.1890/1540-9295(2006) 004[0080:BEFART]2.0.CO;2
FitzSimmons M, Glaser J, Mor RM, Pincetl S, Rajan C (1991) Environmentalism and the liberal state. Capital Nat Social 2:1-16. doi:10.1080/10455759109358424

Folke C, Colding J, Berkes F (2003) Synthesis: building resilience and adaptive capacity in social-ecological systems. Navigating Dynamic Socio-Ecological Systems: Building Resilience for Complexity and Change. Cambridge University Press, Cambridge, pp 352-387

Francis CA, Porter P (2011) Ecology in sustainable agriculture practices and systems. Crit Rev Plant Sci 30:64-73. doi:10.1080/07352689. 2011.554353

Frei M, Becker K (2005) Integrated rice-fish culture: coupled production saves resources. Nat Resour Forum 29:135-143. doi:10.1111/j. 1477-8947.2005.00122.x

Frey D (2011) Bioshelter market garden: a permaculture farm. New Society, Gabriola Island

Fujita K, Ofosu-Budu KG, Ogata S (1992) Biological nitrogen fixation in mixed legume-cereal cropping systems. Plant Soil 141:155-175. doi:10.1007/BF00011315

Geels FW, Kemp R (2007) Dynamics in socio-technical systems: typology of change processes and contrasting case studies. Technol Soc 29:441-455. doi:10.1016/j.techsoc.2007.08.009

Gehron K, Webster J (2012) Invasive plants in permaculture: nonnative invasives, a problem that can't be wished away. In: Native Plants Wildl. Gard. http://nativeplantwildlifegarden.com/invasive-plantsin-permaculture/. Accessed 29 May 2013

Geiger R, Steward MN (1950) The climate near the ground. Harvard University Press, Cambridge

Geist HJ, Lambin EF (2002) Proximate causes and underlying driving forces of tropical deforestation. Bioscience 52:143-150. doi:10. 1641/0006-3568(2002)052[0143:PCAUDF]2.0.CO;2

Glover JD, Reganold JP, Bell LW, Borevitz J, Brummer EC, Buckler ES, Cox CM, Cox TS, Crews TE, Culman SW (2010) Increased food and ecosystem security via perennial grains. Science(Washington) 328:1638-1639. doi:10.1126/science.1188761

Gómez LF, Ríos-Osorio L, Eschenhagen ML (2013) Agroecology publications and coloniality of knowledge. Agron Sustain Dev 33:355362. doi:10.1007/s13593-012-0109-6

Gomiero T, Giampietro M, Bukkens SG, Paoletti MG (1999) Environmental and socioeconomic constraints to the development of freshwater fish aquaculture in China. Crit Rev Plant Sci 18:359-371

Gomiero T, Pimentel D, Paoletti MG (2011) Is there a need for a more sustainable agriculture? Crit Rev Plant Sci 30:6-23. doi:10.1080/ 07352689.2011 .553515

Grayson R (2003) Permaculture an agent of bio-invasion? Planet J Permac Int Ltd 10-11

Grayson R (2010) Permaculture papers 7: into the new century. In: Pac. Edge. http://pacific-edge.info/2010/09/permaculture-papers6/. Accessed 30 May 2013

Grayson, R (2010) The permaculture papers 3: childhood. In: Pac. Edge. http://pacific-edge.info/2010/09/the-permaculture-papers- $2 /$. Accessed 10 Dec 2012

Guitart D, Pickering C, Byrne J (2012) Past results and future directions in urban community gardens research. Urban For Urban Green 11: 364-373. doi:10.1016/j.ufug.2012.06.007

Harb R (2011) UMass Amherst permaculture: leading by example. Communities 153:56-76

Hatfield J (2007) Beyond the edge of the field. In: Pres. Messag.-Arch. Soil Sci. Soc. Am. https://www.soils.org/about-society/presidentsmessage/archive/13. Accessed 29 May 2013

Hatton TJ, Nulsen RA (1999) Towards achieving functional ecosystem mimicry with respect to water cycling in southern Australian agriculture. Agrofor Syst 45:203-214. doi:10. 1023/A:1006215620243

Hawken P (2007) Blessed unrest: how the largest movement in the world came into being and why no one saw it coming. Viking, New York 
He Q (1999) Knowledge discovery through co-word analysis. Libr Trends 48:133-159

Hemenway T (2009) Gaia's garden: a guide to home-scale permaculture, 2nd edn. Chelsea Green, White River Junction

Higgs E (2012) Changing nature: novel ecosystems, intervention, and knowing when to step back. In: Weinstein M, Turner R (eds) Sustain. Springer, New York, pp 383-398

Hobbs RJ, Hallett LM, Ehrlich PR, Mooney HA (2011) Intervention ecology: applying ecological science in the twenty-first century. Bioscience 61:442-450. doi:10.1525/bio.2011.61.6.6

Holmgren D (1992) Uncommon sense: development of the permaculture concept. Permac Int J 44:26-30

Holmgren D (2004) Permaculture: principles and pathways beyond sustainability. Holmgren Design, Hepburn

Holt-Gimenez E (2006) Campesino a campesino: voices from Latin America's farmer to farmer movement for sustainable agriculture. Food First, Oakland

Holzer S (2011) Sepp Holzer's permaculture: a practical guide to smallscale, integrative farming and gardening. Chelsea Green, White River Junction

Howard A (1940) An agricultural testament. Oxford University Press, London

Ingram M (2007) Biology and beyond: the science of back to nature farming in the United States. Ann Assoc Am Geogr 97:298-312. doi:10.1111/j.1467-8306.2007.00537.x

Jacke D, Toensmeier E (2005) Edible forest gardens: ecological design and practice for temperate-climate permaculture. Chelsea Green, White River Junction

Jacke D, Toensmeier E (2006) Edible forest gardens: ecological vision and theory for temperate climate permaculture. Chelsea Green, White River Junction

Jamu DM, Piedrahita RH (2002) An organic matter and nitrogen dynamics model for the ecological analysis of integrated aquaculture/agriculture systems: II. Model evaluation and application. Environ Model Softw 17:583-592. doi:10.1016/S1364-8152(02) 00017-8

Jobbágy EG, Jackson RB (2004) The uplift of soil nutrients by plants: biogeochemical consequences across scales. Ecology 85:2380 2389. doi: $10.1890 / 03-0245$

Jordan CF (1971) A world pattern in plant energetics: studies of the productive potential of natural ecosystems yield insight into how plants use solar energy and how world patterns of energy use could have evolved. Am Sci 59:425-433

Jordan N, Boody G, Broussard W, Glover JD, Keeney D, McCown BH, McIsaac G, Muller M, Murray H, Neal J (2007) Sustainable development of the agricultural bio-economy. Science 316:1570. doi:10. $1126 /$ science. 1141700

Jordan N, Warner KD (2010) Enhancing the multifunctionality of US agriculture. Bioscience 60:60-66. doi:10.1525/bio.2009.60.1.10

Jordan NR, Bawden RJ, Bergmann L (2008) Pedagogy for addressing the worldview challenge in sustainable development of agriculture. J Nat Resour Life Sci Educ 37:92-99

Jose S (2009) Agroforestry for ecosystem services and environmental benefits: an overview. Agrofor Syst 76:1-10. doi:10.1007/s10457009-9229-7

Kadir Alsagoff SA, Clonts HA, Jolly CM (1990) An integrated poultry, multi-species aquaculture for Malaysian rice farmers: a mixed integer programming approach. Agric Syst 32:207-231. doi:10.1016/ 0308-521X(90)90002-8

Kalame FB, Aidoo R, Nkem J, Ajayie OC, Kanninen M, Luukkanen O, Idinoba M (2011) Modified taungya system in Ghana: a win-win practice for forestry and adaptation to climate change? Environ Sci Policy. doi:10.1016/j.envsci.2011.03.011

King FH (1911) Farmers of forty centuries; or, permanent agriculture in China, Korea and Japan. King, Madison

Koohafkan P, Altieri MA, Gimenez EH (2012) Green agriculture: foundations for biodiverse, resilient and productive agricultural systems. Int J Agric Sustain 10:61-75. doi:10.1080/14735903. 2011.610206

Kousha K, Thelwall M (2008) Sources of Google Scholar citations outside the science citation index: a comparison between four science disciplines. Scientometrics 74:273-294. doi:10.1007/ s11192-008-0217-x

Kremen C, Bacon C, Iles A (2012) Diversified farming systems: an agroecological, systems-based alternative to modern industrial agriculture. Ecol Soc 17:44. doi:10.5751/ES-05103-170444

Lancaster B, Marshall J (2008) Water-harvesting earthworks. Rainsource, Tucson

Lawton, G (2008) Establishing a food forest the permaculture way. Eco Films Australia

Leakey RRB (2012) Multifunctional agriculture and opportunities for agroforestry: implications of IAASTD. Agroforestry: the future of global land use. Springer, Dordrecht, pp 203-214

Lefroy EC (1999) Perennial farming systems. Balancing conservation and production in grassy landscapes. South Australia, pp $170-176$

Lefroy EC (2009) Agroforestry and the functional mimicry of natural ecosystems. CSIRO, Melbourne, pp 23-35, Agrofor. Nat. Resour. Manag.

Lockeretz W (2007) Organic farming: an international history. CABI, Wallingford, UK; Cambridge, MA

Lovell ST, Nathan CA, Olson MB, Méndez EV, Kominami HC, Erickson DL, Morris KS, Morris WB (2010) Integrating agroecology and landscape multifunctionality in Vermont: an evolving framework to evaluate the design of agroecosystems. Agric Syst 103:327-341. doi:10.1016/j.agsy.2010.03.003

Malézieux E (2012) Designing cropping systems from nature. Agron Sustain Dev 32:15-29. doi:10.1007/s13593-011-0027-z

Malik K (2013) 2013 Human development report: the rise of the southhuman progress in a diverse world. United Nations Development Program

Marques F (2010) Constructing sociotechnical transitions toward sustainable agriculture. Proc. Symp. Innov. Sustain. Dev. Agric. Food ISDA Montp. Fr. 28 June to 1 July 2010

Mars R (2005) The basics of permaculture design. Chelsea Green, White River Junction

Martin G, Martin-Clouaire R, Duru M (2012) Farming system design to feed the changing world. A review. Agron Sustain Dev 33(1):131149. doi: $10.1007 / \mathrm{s} 13593-011-0075-4$

Martínez-Torres ME, Rosset PM (2010) La Vía Campesina: the birth and evolution of a transnational social movement. J Peasant Stud 37: 149-175. doi:10.1080/03066150903498804

McCormick J (1991) Reclaiming paradise: the global environmental movement, illustrated. Indiana University Press, Bloomington

McIntyre BD, Herren HR, Wakhungu J, Watson RT (2009) Agriculture at a crossroads. Synthesis report

McNeely JA, Scherr SJ (2001) Saving our species: how the earth's biodiversity depends on progress in agriculture. Future Harvest, Washington, DC

Méndez VE, Bacon CM, Cohen R (2013) Agroecology as a transdisciplinary, participatory, and action-oriented approach. Agro Ecol Sustain Food Syst 37:3-18. doi:10.1080/10440046. 2012.736926

Mollison B (1979) Permaculture two: practical design for town and country in permanent agriculture. Tagari, Tasmania

Mollison B (1988) Permaculture: a designer's manual. Tagari, Tasmania

Mollison B (2003) The foundation year-book of the permaculture academy. http://www.patriciamichaeldesign.com/texts/YearBook.pdf. Accessed 14 May 2013

Mollison B, Holmgren D (1978) Permaculture one: a perennial agricultural system for human settlements. Tagari, Tyalgum

Mollison BC, Slay RM (1997) Introduction to permaculture, 2nd edn. Tagari, Tasmania 
Morris C, Winter M (1999) Integrated farming systems: the third way for European agriculture? Land Use Policy 16:193-205. doi:10.1016/ S0264-8377(99)00020-4

Mt. Pleasant J, Burt RF (2010) Estimating productivity of traditional Iroquoian cropping systems from field experiments and historical literature. J Ethnobiol 30:52-79. doi:10.2993/02780771-30.1.52

Mulligan M, Hill S (2001) Ecological pioneers: a social history of Australian ecological thought and action. Cambridge University Press, Cambridge

Mussery A, Leu S, Lensky I, Budovsky A (2013) The effect of planting techniques on arid ecosystems in the northern Negev. Arid Land Res Manag 27:90-100. doi:10.1080/15324982.2012.719574

Nair PKR (1993) An introduction to agroforestry. Kluwer, Dordrecht

Nelson E, Scott S, Cukier J, Galán ÁL (2009) Institutionalizing agroecology: successes and challenges in Cuba. Agric Hum Values 26:233243. doi:10.1007/s10460-008-9156-7

Neuhaus C, Neuhaus E, Asher A, Wrede C (2006) The depth and breadth of Google Scholar: an empirical study. Portal Libr Acad 6:127-141

Newman ME (2006) Modularity and community structure in networks. Proc Natl Acad Sci 103:8577-8582. doi:10.1073/iti2306103

Norgaard RB (1984) Traditional agricultural knowledge: past performance, future prospects, and institutional implications. Am J Agric Econ 66:874-878. doi:10.2307/1241018

Nudds TD (1999) Adaptive management and the conservation of biodiversity. Island, Washington, DC

Ochalla B (2004) Loan zone: branching out green loan incentives blossom at permaculture CU and others. Credit Union Manag 27:34-35

Odum HT (1971) Environment, power, and society. Wiley-Interscience, New York

Odum HT (1994) Ecological and general systems: an introduction to systems ecology. University Press of Colorado, Niwot

Orlandini S, Marta AD, Mancini M (2006) The agroclimatic analysis at farm scale. Meteorol Appl 13:87. doi:10.1017/S1350482706002593

Orr DW (1992) Ecological literacy: education and the transition to a postmodern world. Suny, Albany

Osty P-L (2008) Raisonnement à partir de cas et agronomie des territoires. Rev Anthr Connaissances 2:169-193. doi:10.3917/rac.004.0169

Pálsson G (1996) Human-environmental relations: orientalism, communalism, paternalism. In: Descola P, Pálsson G (eds) Nature and society: anthropological perspectives. Routledge, Evanston, pp 63-81

Pant J, Demaine H, Edwards P (2005) Bio-resource flow in integrated agriculture-aquaculture systems in a tropical monsoonal climate: a case study in Northeast Thailand. Agric Syst 83:203-219. doi:10. 1016/j.agsy.2004.04.001

Paranyushkin D (2011) Identifying the pathways for meaning circulation using text network analysis. Nodus Labs, Berlin

Permaculture Institute (2013) What is permaculture. In: Permac. Inst. http://www.permaculture.org/nm/index.php/site/permaculture design_course. Accessed 30 May 2013

Petersen P, Mussoi EM, Dalsoglio F (2012) Institutionalization of the agroecological approach in Brazil: advances and challenges. J Sustain Agric 37:103-114. doi: 10.1080/10440046.2012.735632

Picasso VD, Brummer EC, Liebman M, Dixon PM, Wilsey BJ (2011) Diverse perennial crop mixtures sustain higher productivity over time based on ecological complementarity. Renew Agric Food Syst 26:317-327. doi:10.1017/S1742170511000135

Piraux M, Silveira L, Diniz P, Duque G, Coudel E, Devautour H, Soulard C, Hubert B (2010) Agroecological transition as a socio-territorial innovation: the case of the territory of Borborema in Brazilian semiarid. Proc. Symp. Innov. Sustain. Dev. Agric. Food Montp. Fr. 28 June to 1 July 2010

Popping R (2003) Knowledge graphs and network text analysis. Soc Sci Inf 42:91-106. doi:10.1177/0539018403042001798
Porder S, Chadwick OA (2009) Climate and soil-age constraints on nutrient uplift and retention by plants. Ecology 90:623-636. doi: $10.1890 / 07-1739.1$

Prein P (2002) Integration of aquaculture into crop-animal systems in Asia. Agric Syst 71:127-146. doi:10.1016/S0308-521X(01)00040-3

Pretty J (2005) Sustainability in agriculture: recent progress and emergent challenges. Issues Environ Sci Technol 21:1-15

Pretty J (2006) Agroecological approaches to agricultural development. World Bank, Washington, DC

Pursell C (1993) The rise and fall of the appropriate technology movement in the United States, 1965-1985. Technol Cult 34:629-637

Rasul G, Thapa GB (2003) Shifting cultivation in the mountains of South and Southeast Asia: regional patterns and factors influencing the change. Land Degrad Dev 14:495-508. doi: $10.1002 / 1 d r .570$

Reich L (2010) Why I'm not a permaculturist. In: Gard. Rant. http:// gardenrant.com/2010/03/why-im-not-a-permaculturist.html. Accessed 28 May 2012

Reijntjes C, Haverkort B, Waters-Bayer A (1992) Farming for the future: an introduction to low-external-input and sustainable agriculture. Macmillan, London

Rocha JM (2005) Measuring traditional agro-ecological knowledge: an example from peasants in the Peruvian Andes. Field Methods 17: 356-372. doi:10.1177/1525822X05275380

Rockström J, Karlberg L, Wani SP, Barron J, Hatibu N, Oweis T, Bruggeman A, Farahani J, Qiang Z (2010) Managing water in rainfed agriculture: the need for a paradigm shift. Agric Water Manag 97:543-550. doi:10.1016/j.agwat.2009.09.009

Romanowski N (2007) Sustainable freshwater aquaculture: the complete guide from backyard to investor. UNSW Press, Sydney

Rosset PM, Martínez-Torres ME (2012) Rural social movements and agroecology: context, theory, and process. Ecol Soc 17:17. doi:10. 5751/ES-05000-170317

Rosset PM, Sosa BM, Jaime AMR, Lozano DRÁ (2011) The campesinoto-campesino agroecology movement of ANAP in Cuba: social process methodology in the construction of sustainable peasant agriculture and food sovereignty. J Peasant Stud 38:161-191. doi: $10.1080 / 03066150.2010 .538584$

Rukera ST, Mutanga O, Micha J-. C (2012) Optimization of an integrated rabbit-fish-rice system for sustainable production in Rwanda. Rwanda J 24

Sanford AW (2011) Ethics, narrative, and agriculture: transforming agricultural practice through ecological imagination. J Agric Environ Ethics 24:283-303. doi:10.1007/s10806-010-9246-6

Scherr SJ, McNeely JA (2008) Biodiversity conservation and agricultural sustainability: towards a new paradigm of ecoagriculture landscapes. Phil Trans R Soc B Biol Sci 363:477-494. doi:10.1098/ rstb.2007.2165

Schoeneberger M, Bentrup G, de Gooijer H, Soolanayakanahally R, Sauer T, Brandle J, Zhou X, Current D (2012) Branching out: agroforestry as a climate change mitigation and adaptation tool for agriculture. J Soil Water Conserv 67:128A-136A. doi:10.2489/ jswc.67.5.128A

Scott R (2010) A critical review of permaculture in the United States - a critical review of permaculture. In: http://robscott.net/, http:// robscott.net/2010/comments/. Accessed 29 May 2013

Seastedt TR, Hobbs RJ, Suding KN (2008) Management of novel ecosystems: are novel approaches required? Front Ecol Environ 6:547553. doi:10.1890/070046

Shepard M (2013) Restoration agriculture: real world permaculture for farmers. Acres U.S.A., Austin

Sherard JL, Decker RS, Dunnigan LP (1976) Identification and nature of dispersive soils. J Geotech Eng Div 102:287-301

Simberloff D, Dayan T (1991) The guild concept and the structure of ecological communities. Annu Rev Ecol Syst 22:115-143. doi: 10. 1146/annurev.es.22.110191.000555 
Smith C (2002) Learning for the environment: an examination of personal empowerment through learning permaculture. Post Scr 3:12-25

Smith JR (1929) Tree crops: a permanent agriculture. New York Brace \& Co, New York

Smukler S, Sánchez-Moreno S, Fonte S, Ferris H, Klonsky K, O'Geen A, Scow K, Steenwerth K, Jackson L (2010) Biodiversity and multiple ecosystem functions in an organic farmscape. Agric Ecosyst Environ 139:80-97. doi:10.1016/j.agee.2010.07.004

Soleil S (2012) The Biochar Miracle. In: Permac. Res. Inst. - Permac. Forums Courses Inf. News. http://permaculturenews.org/2012/02/ 03/the-biochar-miracle/. Accessed 28 May 2013

Sterk S, van Ittersum MK, Leeuwis L, Rossing R, van Keulen H, Van de Ven GWJ (2006) Finding niches for whole-farm design models - contradictio in terminis? Agric Syst 87:211-228. doi:10.1016/j.agsy.2004.11.008

Strongman L (2012) Modern nature: essays in environmental communication. Universal, Boca Raton

Tacio HD (1993) Sloping agricultural land technology (SALT): a sustainable agroforestry scheme for the uplands. Agrofor Syst 22:145-152. doi:10.1007/BF00705143

Taghavi A, Murat A (2011) A heuristic procedure for the integrated facility layout design and flow assignment problem. Comput Ind Eng 61:55-63. doi:10.1016/j.cie.2011.02.011

Talpaz H, Tsur Y (1982) Optimising aquaculture management of a singlespecies fish population. Agric Syst 9:127-142. doi:10.1016/0308521X(82)90027-0

Tipraqsa P, Craswell ET, Noble AD, Schmidt-Vogt D (2007) Resource integration for multiple benefits: multifunctionality of integrated farming systems in Northeast Thailand. Agric Syst 94:694-703. doi:10.1016/j.agsy.2007.02.009

Todd NJ (2005) A safe and sustainable world: the promise of ecological design. Island Washington, DC

Toensmeier E (2007) Perennial vegetables: from artichoke to zuiki taro, a gardener's guide to over 100 delicious, easy-to-grow edibles. Chelsea Green, White River Junction

Toensmeier E (2011) Perennial staple crops of the world. Permac Act 81

Toensmeier E, Bates J (2013) Paradise lot: two plant geeks, one-tenth of an acre, and the making of an edible garden oasis in the city. Chelsea Green, White River Junction

Torre Ugarte DG, Hellwinckel CC (2010) The problem is the solution: the role of biofuels in the transition to a regenerative agriculture. In:
Mascia P, Scheffran J, Widholm J (eds) Plant biotechnology for sustainable production of energy and co-products. Springer, New York, pp 365-384

Uuemaa E, Mander Ü, Marja R (2012) Trends in the use of landscape spatial metrics as landscape indicators: a review. Ecol Indic. doi:10. 1016/j.ecolind.2012.07.018

Vandermeer J (1995) The ecological basis of alternative agriculture. Annu Rev Ecol Syst 26:201-224. doi: 10.1146/annurev.es.26.110195. 001221

Veldkamp A, Kok K, De Koning GHJ, Schoorl JM, Sonneveld MPW, Verburg PH (2001) Multi-scale system approaches in agronomic research at the landscape level. Soil Tillage Res 58:129-140. doi:10. 1016/S0167-1987(00)00163-X

Venkatadri U, Rardin RL, Montreuil B (1997) A design methodology for fractal layout organization. IIE Trans 29:911-924. doi:10.1080/ 07408179708966411

Wezel A, Bellon S, Doré T, Francis C, Vallod D, David C (2009) Agroecology as a science, a movement and a practice. A review. Agron Sustain Dev 29:503-515. doi:10.1051/agro/2009004

Wezel A, Soldat V (2009) A quantitative and qualitative historical analysis of the scientific discipline of agroecology. Int J Agric Sustain 7: 3-18. doi:10.3763/ijas.2009.0400

Whitefield P (2004) The Earth care manual: a permaculture handbook for Britain \& other temperate climates. Permanent, Portsmouth

Williams G (2012) A must read for permaculturists. HortIdeas 29:3

Williams G, Polk E, Warshall P (2001) Permaculture: hype or hope? Whole Earth. Winter 90-92

Wilson GA (2008) From "weak" to "strong" multifunctionality: conceptualising farm-level multifunctional transitional pathways. J Rural Stud 24:367-383. doi:10.1016/j.jrurstud.2007.12.010

WPP Research (2013) Woody perennial polyculture research|WPP Research. In: Woody Perenn. Polycult. Res. Site. http:// wppresearch.org/. Accessed 29 May 2013

Yeomans PA (1954) The Keyline plan. PA Yeomans, Sydney

Yeomans PA (1981) Water for every farm: using the Keyline plan. Second Back Row, Katoomba

Yeomans PA (1958) The challenge of landscape: the development and practice of Keyline. Keyline Pub. Pty, Sydney

Yeomans PA (1971) The city forest: the Keyline plan for the human environment revolution. Keyline Publishing Pty., Sydney 